\title{
Corporate Aging and Takeover Risk*
}

\author{
CLAUDIO LODERER ${ }^{1}$ and URS WAELCHLI ${ }^{2}$ \\ ${ }^{1}$ University of Bern, Swiss Finance Institute and ${ }^{2}$ Rochester-Bern Executive \\ Programs, University of Rochester
}

\begin{abstract}
Although growth opportunities fade and profitability declines as firms mature, older firms are no more likely to be acquired than young firms are. This article documents and explains that phenomenon. We argue that, because mature organizations are rationally less flexible, they are more costly to integrate and therefore comparatively unattractive acquisition candidates. The evidence supports this explanation of the negative age dependence of takeover hazard. The evidence also shows that negative exogenous shocks to merger benefits further reduce the takeover hazard of mature firms. We test many alternative explanations and find no evidence that they can explain the hazard decline.
\end{abstract}

JEL Classification: G30, L20

\section{Introduction}

According to Fama and French (2004), the 10-year survival rate of listed firms is only $53 \%$. The main exit risk is takeover, which has a 10 -year probability of $32 \%$ among seasoned firms and $22 \%$ among new lists. Takeover risk seems to increase as firms get older. The evidence in Loderer, Stulz, and Waelchli (2014) could explain why that is the case. Accordingly, more established (older) firms are less profitable, have fewer growth opportunities,

\footnotetext{
* We are indebted to an anonymous referee and to Vikrant Vig (the editor) for all the help they provided. We have benefited from comments and suggestions by Yakov Amihud, Demian Berchtold, Øyvind Bohren, Michael Brennan, Lorenzo Bretscher, Gian Luca Clementi, Francois Degeorge, Espen Eckbo, Stephen Jenkins (especially), David Haushalter, Jean Helwege, Cliff Holderness, Peter Iliev, Yoram Landskroner, Michael Lemmon, Diego Liechti, John McConnell, Erwan Morellec, Stewart Myers, Klaus Neusser (especially), Maureen O’Hara, Adriano Rampini, Lukas Roth, Markus Senn, Dennis Sheehan, René Stulz, Karin Thorburn, Heather Tookes, and Jonas Zeller. We are also grateful for the critical remarks by seminar participants at the Norwegian School of Management, Penn State University, the University of Bern, the University of Lugano, and the Stockholm School of Economics, as well as by participants at the European Winter Finance Conference, the Frontiers in Finance Conference, the AFFI conference, the Swiss Finance Institute Research Day, and the European Finance Association meetings. Financial support from the Swiss Finance Institute is gratefully acknowledged. All errors are ours.
} 
engage in less $\mathrm{R} \& \mathrm{D}$, invest less, and generally score more poorly on corporate governance indices. Their governance structures might therefore be inadequate to bring about change and instill new life into the organization (Scharfstein, 1988; Morck, Shleifer, and Vishny, 1989). If so, takeover could enforce restructuring, and its hazard should indeed increase over time. This article examines whether that is the case and, if not, why.

Using a large sample of US listed firms over the period 1978-2009, we test whether mature firms are more likely to delist because of takeover. The evidence strongly rejects this prediction. The takeover hazard drops significantly as firms get older. The decline in takeover hazard is more or less continuous and economically tangible. For example, compared with a 5 -year-old firm, the takeover hazard of a 25 -year-old firm can be as much as $32 \%$ lower. Since hazards are conditional probabilities, their decline is not necessarily induced by sheer survival.

The remainder of the article is dedicated to explaining the phenomenon of the negative age-dependence of takeover hazard. We first examine whether the effect is driven by firm characteristics that have been found to correlate with takeover risk. These characteristics include firm size (Comment and Schwert, 1995; Cooley and Quadrini, 2001), financial frictions (Hadlock and Pierce, 2010), growth-resource imbalances (Palepu, 1986), management inefficiency (Manne, 1965; Jensen, 1986, 1993), asset mispricing (Palepu, 1986; Jovanovic and Rousseau, 2002), cash holdings and borrowing capacity (Bruner, 1988), potential overinvestment problems (Lehn and Poulsen, 1989), manager age, the presence of CEOs in retirement age (Jenter and Lewellen, 2014), the age of the firm's product market lines, and the availability of merger partners with similar products, size, and valuation multiples (Rhodes-Kropf and Robinson, 2008; Hoberg and Phillips, 2010), among others. Many of these variables, such as firm size, cash holdings, and the similarity measures, are proxies suggested in the literature for the synergistic value of the acquisition of the firm in question. According to the evidence, the age-related decline of takeover risk remains even after controlling for these effects. Hence, general lack of synergies does not seem to explain this finding. This remains so also when controling for competing exit risks as well as for unobserved heterogeneity.

We also find no evidence that overpricing of the stock of established firms is what discourages takeover. Furthermore, the negative age dependence of merger hazard does not seem to be driven by a search-cost hypothesis, according to which older firms simply survived the screening by potential acquirers and therefore face an increasingly smaller pool of interested partners to merge with. 
If established firms are comparatively less frequently involved in takeovers, it must ultimately be because they resist takeover or because they are comparatively more costly to integrate into other organizations. We test these two interpretations of the evidence. According to the takeoverresistance interpretation, managers could have a preference for a quiet life (Hicks, 1935; Bertrand and Mullainathan, 2003; Giroud and Mueller, 2010) and therefore decide to work less and simply milk the available lines of business. Managers might therefore resist takeover for fear of compromising their quiet life. If the managers of mature firms had less valuable outside employment opportunities, such takeover resistance would be particularly pronounced there. Yet we find little evidence that older firms erect antitakeover barriers. If anything, they take them down.

The alternative interpretation for why established firms are comparatively unattractive takeover targets is because of higher integration costs. These costs can be quite substantial. According to a recent survey conducted by EY (2014), firms, on average, spend $14 \%$ of the deal value on merger integration.

Holmstrom (1989) argues that established firms primarily serve production and marketing goals. To pursue these goals, mature firms rationally depend on rules that induce bureaucratization and compromise innovation. Since this focusing process takes time, these "rigidities" (Leonard-Barton, 1992) accumulate over time and render mature firms increasingly impervious to change (Henderson, 1993; Gompers, Lerner, and Scharfstein, 2005). Because of these rigidities, established firms are more costly to integrate in different organizations, which could explain why takeover risk drops with firm age. We conduct two separate tests of this integration costs interpretation of the negative age-dependence of takeover risk and find supporting evidence.

The first test looks at how negative exogenous industry shocks affect takeover risk at older age. The assumption is that merger integration costs do not depend strongly on business conditions. Merger benefits, however, are positively related to business conditions. At times of adverse shocks to business conditions, firms with high merger integration costs should have particularly low takeover hazards because the gains to takeover drop whereas the integration costs remain constant. To the extent that firm age is a proxy for integration costs, we would therefore expect that the takeover risk of old firms falls further at times of industry distress. The evidence supports this prediction. To test it, we follow Opler and Titman (1994) and Gopalan and Xie (2011), among others, and assume that an industry is in distress if median sales growth is negative and median stock return is below $-30 \%$. Compared with normal times, we find that the predicted 
takeover hazard of a mature firm drops by almost $50 \%$ at times of industry distress (from $3.7 \%$ to $1.7 \%$ ), whereas that of a young firm is unaffected $(4.1 \%)$. This shock test controls for the synergistic value of the sample firms. Hence, it does not depend on the distribution of potential synergies that can be achieved from merging with old or young firms.

The second test looks for distinctive symptoms of corporate rigidities and asks whether they can explain the negative age-dependence of takeover risk. The rigidities we consider refer to the firm's cost structure, its investment policy, its product portfolio, as well as its organizational structure. All rigidity measures correlate positively and strongly with firm age. Moreover, the presence of these rigidities reduces takeover hazard significantly. However, individually, these rigidities fail to explain the negative age effect we find. Only when we combine them in the same regression does the age effect disappear, whereas the individual rigidity measures maintain their negative and significant influence. Therefore, the evidence implies that it is not a single type of rigidity that renders established firms unattractive merger partner but the accumulation of such rigidities.

This article focuses on takeover hazard, the main exit hazard of listed firms. However, because we control for competing risks in our econometric approach, the investigation also provides new insights into the age-dependence of financial failure hazard. We find that the failure hazard of firms declines with age, too. The extant empirical literature reports inconclusive results in this respect, although theoretical priors predict a decline. For example, studies on the dynamics of the firms' investment behavior (Cooley and Quadrini, 2001), learning (Jovanovic, 1982; Pastor and Veronesi, 2003), and access to the capital market (Hadlock and Pierce, 2010) imply declining failure hazards over time. Shumway (2001), however, finds no relation between listing age and bankruptcy probability. Since we control for all the standard variables that have been found to influence financial failure, the decline in failure hazard we uncover can hardly be explained with factors such as low leverage, low uncertainty, or better profitability. One possible interpretation is that mature firms have better networks and are therefore better at achieving out-of-court solutions for their financial problems. At the same time, because of these connections, creditors are more reluctant to force these firms into bankruptcy since the reputation costs of doing so are comparatively high. During times of industry distress, however, we find that the hazard of financial failure more than doubles for mature firms. Possible interpretations are that financial failure serves as an alternative crisis resolution mechanism to takeover (Stiglitz, 1972; Shrievens and Stevens, 1979; Pastena and Ruland, 1986; 
Jensen, 2000), or that generalized distress allows creditors to trigger the bankruptcy filing of mature firms without having to bear the blame.

Taken together, the article makes the following contributions to the literature. First, we document that takeover hazard declines with age, even in the context of competing hazards and controlling for unobserved heterogeneity. Second, the article explains that decline. Older firms are comparatively unattractive acquisition candidates at current market prices because, with their rigid structures, they are more costly to integrate. Third, we contribute to a better understanding of takeover as the main mechanism of resource allocation in the economy, and therefore to a better understanding of the dynamics of economic growth. Growth is accompanied by frequent reallocations and recycling of resources via takeover. That reallocation process, however, abates when it comes to mature firms.

The remainder of the article proceeds as follows. Section 2 describes the sample and discusses the empirical strategy. Section 3 studies the relation between firm age and takeover hazard. It also discusses the economic relevance of the age-related decline in exit hazards we find. Section 4 asks whether that negative dependence could reflect an attempt by the managers of older firms to keep their firms independent. Section 5 examines whether it is comparatively higher integration costs that render mature firms unattractive takeover candidates. Section 6 briefly discusses the age-dependence of failure hazard. Finally, Section 7 presents conclusions.

\section{Sample Description and Research Design}

\subsection{SAMPLE DESCRIPTION}

The sample consists of all listed firms with data on CRSP, COMPUSTAT, and COMPUSTAT Industry Segment between 1978 and 2009. We exclude utilities as well as firms in the financial sector of the economy (SIC 60006999). Moreover, we ignore firm-years with negative total assets or sales, missing data on COMPUSTAT Segments, and cumulative sales on the COMPUSTAT Segments tapes which deviate by more than $1 \%$ from the total sales reported on the COMPUSTAT tapes. We omit all firms that have been listed for less than 5 years because of the finding in Bhattacharya, Borisov, and $\mathrm{Yu}$ (2014) that "natal financial care" significantly affects firm mortality rates during the first years after listing. The results are qualitatively the same when we include these firms. We also drop all three-digit SIC industry-years with fewer than five observations, as we need to estimate moments of the industry-wide distribution of the variables to control for 
Table I. Turnover and exit reasons

The table distinguishes various subperiods and shows the number of sample firms at the beginning of each period as well as the number of entering and exiting firms. The last three columns to the right show the reasons why firms leave the sample. Using the delisting codes reported on the CRSP tapes, we distinguish among three exit reasons: takeover, failure, and other reasons. Failure is assumed if a firm is liquidated (delisting codes 400-490), drops from the exchange because of bankruptcy (574), or fails to maintain an acceptable shareprice level (552) or capitalization (560 and 584), fails to file financial statements, or fails to pay exchange fees (580). Takeovers are identified with the delisting codes 200-299. "Other" delistings are mainly exchanges for other securities, switches to other stock exchanges, or delistings because of an insufficient number of shareholders or market makers.

\begin{tabular}{llrrrrr}
\hline \multirow{2}{*}{ Period } & \multirow{2}{*}{ Firms beginning } & New entrants & Total exits & \multicolumn{3}{c}{ Exit reasons } \\
\cline { 5 - 7 } & & & & Takeover & Failure & Other \\
\hline $1978-84$ & 2,324 & 1,276 & 788 & 488 & 107 & 193 \\
$1985-89$ & 2,414 & 1,512 & 1,042 & 532 & 279 & 231 \\
$1990-94$ & 2,777 & 1,315 & 834 & 329 & 387 & 118 \\
$1995-99$ & 3,030 & 1,928 & 1,364 & 825 & 339 & 200 \\
$2000-04$ & 3,018 & 1,435 & 1,303 & 606 & 495 & 202 \\
$2005-09$ & 2,611 & 468 & 1,107 & 714 & 224 & 169 \\
Total & & 7,934 & 6,438 & 3,494 & 1,831 & 1,113 \\
\hline
\end{tabular}

industry effects. The three-digit SIC granularity is the one recommended by Giroud and Mueller (2010), among others. The results are robust to alternative industry definitions. The final sample consists of 10,219 firms and 83,790 firm-years.

Table I reports the number of firms that enter and leave the sample during the 31 years under investigation. We start with 2,324 firms in 1978. Turnover is remarkably high: 7,934 firms enter and 6,438 firms leave between 1978 and 2009. That corresponds to an annual rate of entry and exit of $9.4 \%$ and $7.7 \%$, respectively. ${ }^{1}$ Churn is therefore substantially higher than in the sample of Baker and Kennedy (2002). This is mostly due to the fact that our sample includes the takeover waves of the late 1990s. The results of our investigation remain the same if we exclude the years 1996-2000.

\footnotetext{
1 Note that the sum of firms at the beginning of each subperiod plus new entries minus exits is lower than the number of firms at the beginning of the following subperiod. The difference is due to firms that drop out of the sample because they cease to meet our sample selection criteria. In particular, we lose many observations because of the restriction of at least five firms in each industry-year.
} 
The table also shows the exit reasons based on the delisting codes reported in CRSP. As in Rauh (2006), among others, takeovers are transactions with the delisting codes 200-299. We are unable to tell friendly from hostile deals. Andrade, Mitchell, and Stafford (2001), however, show that even in the 1980 s, the era of hostile takeovers, the overwhelming majority of all deals were friendly (see also Servaes, 1991). Moreover, Schwert (2000) finds that "hostility" is mainly motivated by strategic bargaining to extract higher rents, and that hostile and friendly deals are mostly indistinguishable in economic terms.

Because most of our investigation controls for competing exit risks, we identify forms of exit other than takeover. In the case of financial failure, we follow Campbell, Hilscher, and Szilagyi's (2008) broader failure definition and define it as liquidation (400-490), bankruptcy (574), or delisting for financial reasons. The latter category applies to firms unable to maintain an acceptable share-price level (552) or capitalization amount (560 and 584), or when they fail to file financial statements or pay exchange fees (580). Other forms of exit are comparatively less frequent. The fate of these firms is not apparent from CRSP's delisting codes. We treat them as a separate group in our competing hazard estimation approach. The results are fairly robust to alternative definitions of this group.

Some of the firms that drop from the exchanges in going-private transactions may list again years later, for example in a reverse leveraged buyout (LBO). Cao and Lerner (2009) identify 526 such transactions between 1981 and 2003. Firms that relist could end up being treated as separate firms. This could bias the results. We follow the extant literature and use Compustat's unique identifier (gvkey) to track companies over time in spite of name or ticker changes and measure age from the date of incorporation. Firms typically maintain their incorporation age when they resurface as newly listed entities. Reverse LBOs should therefore not represent a confounding event.

Most firms are taken over or merged $(3,494)$, consistent with Baker and Kennedy (2002). Comparatively few companies $(1,831)$ experience financial failure. Over the whole sample period, takeovers account for roughly $55 \%$ of all exits, $28 \%$ are failures, and $17 \%$ are other kinds of exits. Put differently, of all 10,219 firms present at some time in the sample during 1978-2009, $34 \%$ are taken over, $18 \%$ fail, and $11 \%$ exit for other reasons-the rest survive.

\subsection{EXIT HAZARD ANALYSIS}

The first part of the analysis investigates whether a firm's takeover risk is a function of age. We start with a univariate analysis and then switch to a 
multivariate regression framework to control for potential confounding effects. As mentioned in Section 1, takeover and other exit forms could be competing hazards, a situation that could occur if firms, for example, filed for bankruptcy to avoid takeover or if takeover served as an alternative crisis resolution mechanism for financial failure. Ignoring competing risks can lead to estimation bias (Powell and Yawson, 2007). We therefore investigate the relation between firm age and takeover risk in the context of discrete-time competing risk proportional hazard models. When doing so, we assume that the risk of takeover conditional on the effect of the covariates in the model (in particular profitability) is independent of the risk of financial failure and other exit forms. The model is implemented as a pooled multinomial logistic model (Cameron and Trivedi, 2005; Jenkins, 2005), an approach that offers the advantage that the likelihood function can be computed more easily. In the estimation, we allow for right censoring and correct the standard errors for heteroskedasticity as well as firm clustering. Right censoring occurs because, at the end of the sample period, all we know is when survival time has begun but not when exit (if any) occurs.

Our takeover hazard model includes a broad range of control variables that have been found to correlate with takeover hazard, namely:

\begin{tabular}{|c|c|c|}
\hline Variable & Description & Expected sign \\
\hline Sales growth & Relative change in real sales & ? \\
\hline MTB equity & Market value of equity divided by its book value. & ? \\
\hline Cash & $\begin{array}{l}\text { Cash and short-term investments divided by the book } \\
\text { value assets }\end{array}$ & $? /+$ \\
\hline Debt ratio & Book value of debt divided by market assets & $? /-$ \\
\hline Profitability & Net income divided by lagged total assets & - \\
\hline Excess return & Market-adjusted stock return over the previous year & - \\
\hline Tangibility & Property, plant, and equipment divided by book assets & + \\
\hline Size & Log of the market value of assets & - \\
\hline Focus & Herfindahl index of the firm's segment sales & + \\
\hline MTB similarity & $\begin{array}{l}\text { The fraction of other firms in the same three-digit SIC } \\
\text { industry with a similar MTB equity ratio }\end{array}$ & + \\
\hline Product similarity & $\begin{array}{l}\text { The total product similarity score from Hoberg and } \\
\text { Phillips (2010) }\end{array}$ & + \\
\hline Size similarity & $\begin{array}{l}\text { The fraction of other firms in the same three-digit SIC } \\
\text { industry with a similar market capitalization }\end{array}$ & + \\
\hline Industry concentration & $\begin{array}{l}\text { Herfindahl index of the sales of all firms in the same three- } \\
\text { digit SIC industry }\end{array}$ & - \\
\hline Takeover intensity & $\begin{array}{l}\text { The number of other firms in the same three-digit SIC } \\
\text { industry that delist due to takeover, divided by the } \\
\text { number of other firms in that industry }\end{array}$ & + \\
\hline GDP growth & $\begin{array}{l}\text { The relative change in the real US gross domestic product } \\
\text { in any given year }\end{array}$ & + \\
\hline
\end{tabular}


The precise definition of these variables is in Table AI. Sales growth, equity market-to-book ratios, cash holdings, and debt ratios reflect growth opportunities as well as potential imbalances between growth and available resources (see, e.g., Palepu, 1986). Their effect cannot be signed a priori. Large cash holdings and low debt levels could also be proxies for free cash flow problems, which could attract takeover (Jensen, 1986). Profitability and excess return are related to management efficiency and reduce takeover threat (Jensen, 1988; Scharfstein, 1988). Asset tangibility increases borrowing capacity and, therefore, should invite takeover. Large (Palepu, 1986) and diversified (Agarwal and Gort, 1996, 1999, 2002) firms should face lower takeover risk. Rhodes-Kropf and Robinson (2008) show that merger transactions are more likely to occur between firm with similar characteristics. Similar valuation multiples should therefore invite takeover, and so should the presence of firms with similar size and product lines (see also Hoberg and Phillips, 2010). Many of these variables are proxies for merger synergies. Finally, higher competition and greater takeover activity should increase takeover threat (Kole and Lehn, 1997, 1999) and so should an expanding economy.

To investigate takeover in the context of competing hazards, we have to also investigate failure hazards. To do so, we augment the takeover hazard model by two additional variables that, according to Bharath and Shumway (2008), drive financial failure hazards, namely:

\begin{tabular}{lll}
\hline Variable & Description & Expected sign \\
\hline Naïve PD & The "naïve" default probability implied by Merton's (1974) model & + \\
1/Volatility & The inverse of the standard deviation of return on the firm's stock & - \\
\hline
\end{tabular}

Throughout the analysis, all regression arguments are lagged by 1 year, since exit presumably reacts to its determining factors with a lag. Moreover, to control for industry- and period-specific effects, we standardize all firmspecific variables by industry and year. In other words, we deduct the threedigit SIC industry average and divide by the industry standard deviation in any given year. The exceptions in this standardization are the variables related to company age and Merton model's "naïve" default probability. Standardized variables are denoted with the prefix s-. When interpreting the evidence, it is important to remember this adjustment. The results remain qualitatively the same when we include industry and year-fixed effects instead of standardizing the control variables. Binary variables have the prefix b-. 
Duration dependence could be induced by unobserved heterogeneity in exit hazards (e.g., Zorn, 2000). If the exit hazards of firms are conditionally different in ways we do not account for, the mean hazard rate could decline with cohort age because the sample becomes increasingly composed of firms with the lowest exit risk, and not because exit risk declines with age (see also Thompson, 2005). To address this concern, we also estimate discrete time proportional hazard regressions with the Prentice and Gloeckler (1978) model, which incorporates a gamma mixture distribution to summarize unobserved individual heterogeneity, as well as with the Heckman and Singer (1984) procedure that incorporates a discrete mixture distribution to summarize unobserved individual heterogeneity.

\subsection{VARIABLE DEFINITIONS}

Our main variable of interest is firm age, measured as the number of years (plus one) elapsed since the year of incorporation (Age). Information about the firm's incorporation age is partly from Jay Ritter's website and partly hand-collected from Mergent Webreports. We rely on the firm's incorporation age because firms are subject to exit risk from the day they start. The results remain essentially unchanged when we focus on listing age instead (not tabulated).

Table AII in the Appendix shows average incorporation age and, for comparison, listing age. In the full sample, average listing age is 17 years and average incorporation age is 34 years (the median values are 13 and 25, respectively). Average incorporation age at the time of listing varies substantially over time (see also Jovanovic and Rousseau, 2001; Fink et al., 2010).

To reduce the influence of outliers, we winsorize all continuous and unbounded control variables at the 1st and 99th percentile of their pooled distribution. All variables are measured at year end. Variable definitions are in Table AI and descriptive statistics are in Table AII.

\section{Firm Age and Takeover Hazard}

\subsection{SINGLE-DESTINATION MODELS}

To investigate the relation between firm age and takeover hazard, we start by estimating kernel-weighted local polynomial regressions, a nonparametric technique that helps us identify an unspecified relation between firm age and takeover risk. Figure 1 plots the results of this analysis. The shaded area shows the $90 \%$ confidence interval. To limit the impact of outliers at higher age, we truncate the sample at incorporation age 75 years, the 90 th- 


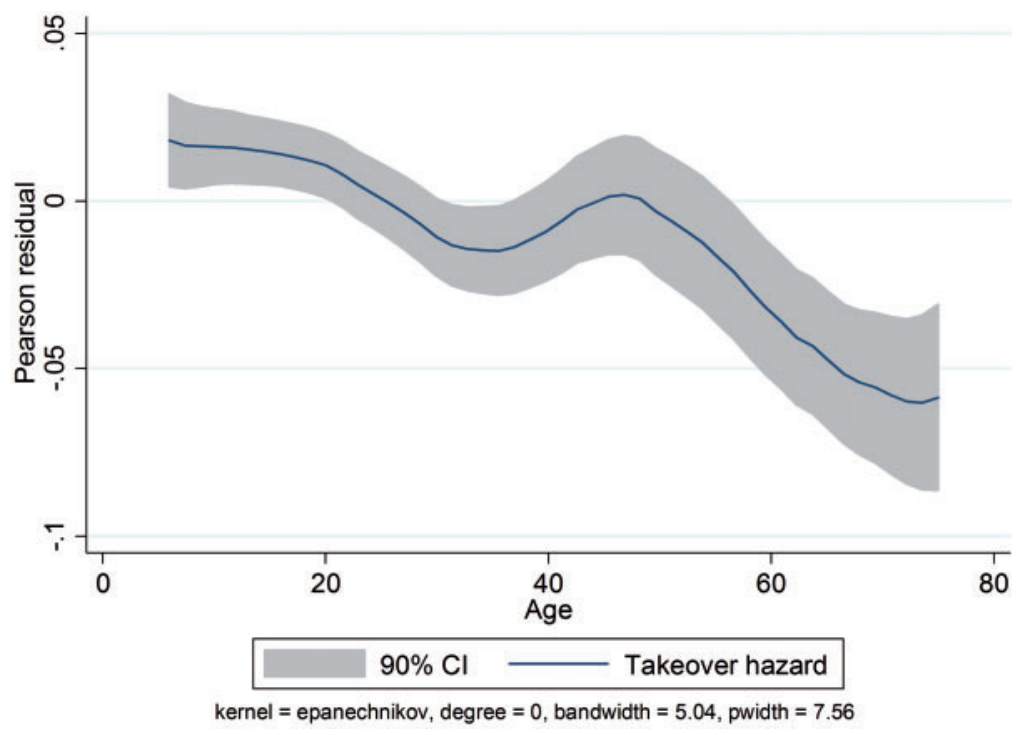

Figure 1. The relation between age and exit risk. The figure reports unconditional kernelweighted local polynomial regressions for takeover risks as a function of firm age, using an Epanechnikov kernel function with a "rule-of-thumb" bandwidth estimator and local-mean smoothing. The shaded area shows the $90 \%$ confidence interval.

percentile of the age distribution, an approach also used by Agarwal and Gort (2002). The results of the estimation imply that takeover hazard declines over time. At young age, it is around $4.5 \%$, whereas at old age it is only around $2.5 \%$. This corresponds to a decline by more than $40 \%$. Takeover hazard seems to rebound slightly around age 40 years, but the increase is not statistically significant.

Table II estimates single destination regressions for takeover hazard that control for unobserved heterogeneity. The first three regressions are univariate. The results imply that the negative age dependence of takeover hazard is robust to unobserved heterogeneity. In Regression 1, we estimate the Prentice and Gloeckler (1978) model that incorporates a gamma mixture distribution to summarize unobserved firm heterogeneity (Meyer, 1990). In that regression, age takes on a negative and significant coefficient. The same result obtains in Regression 2, where we incorporate a discrete mixture distribution to summarize unobserved heterogeneity, as suggested by Heckman and Singer (1984). Finally, Regression 3 shows that the coefficient of age is essentially unchanged when we estimate a proportional hazard model that ignores unobserved heterogeneity. 
Table II. Company age and takeover hazard

The table investigates the relation between firm age and takeover hazard with discrete-time proportional hazard models. Variable definitions are in Table AI. Regressions 1-3 are univariate whereas Regressions 4-6 incorporate the control variables for takeover risk. In Regressions 1, 4, and 5, we estimate Prentice and Gloeckler (1978) discrete-time proportional hazard models incorporating a gamma mixture distribution to summarize unobserved firm heterogeneity (Meyer, 1990). Regressions 2 and 6 estimate Heckman and Singer (1984) models that incorporate a discrete mixture distribution to summarize unobserved heterogeneity (Jenkins, 2005). Finally, for comparison, Regression 3 estimates a discrete-time proportional hazard model that ignores unobserved heterogeneity. Standard errors are clustered at the firm level and reported in parentheses. The symbol *** indicates significance at the $1 \%$ two-tailed level, respectively.

\begin{tabular}{|c|c|c|c|c|c|c|}
\hline & \multirow{2}{*}{$\begin{array}{l}\text { Prentice and } \\
\text { Gloeckler (1978) } \\
\text { (1) }\end{array}$} & \multirow{2}{*}{$\begin{array}{c}\text { Heckman and } \\
\text { Singer (1984) } \\
\text { (2) }\end{array}$} & \multirow{2}{*}{$\begin{array}{l}\text { No control for } \\
\text { unobserved } \\
\text { heterogeneity } \\
\text { (3) }\end{array}$} & \multicolumn{2}{|c|}{$\begin{array}{c}\text { Prentice and } \\
\text { Gloeckler (1978) }\end{array}$} & \multirow{2}{*}{$\begin{array}{c}\text { Heckman and } \\
\text { Singer (1984) } \\
\text { (6) }\end{array}$} \\
\hline & & & & (4) & (5) & \\
\hline $\ln ($ Age $)$ & $\begin{array}{l}-0.179 * * * \\
(0.028)\end{array}$ & $\begin{array}{l}-0.179 * * * \\
(0.027)\end{array}$ & $\begin{array}{l}-0.181 * * * \\
(0.027)\end{array}$ & & $\begin{array}{l}-0.145^{* * *} \\
(0.036)\end{array}$ & $\begin{array}{l}-0.145^{* * *} \\
(0.032)\end{array}$ \\
\hline s Sales growth & & & & $\begin{array}{l}-0.119 * * * \\
(0.021)\end{array}$ & $\begin{array}{l}-0.118^{* * *} \\
(0.024)\end{array}$ & $\begin{array}{l}-0.118^{* * *} \\
(0.024)\end{array}$ \\
\hline s MTB equity & & & & $\begin{array}{c}-0.086^{* * * *} \\
(0.025)\end{array}$ & $\begin{array}{c}-0.093^{* * *} \\
(0.028)\end{array}$ & $\begin{array}{c}-0.093^{* * *} \\
(0.028)\end{array}$ \\
\hline s Cash & & & & $\begin{array}{l}-0.058^{* * * *} \\
(0.021)\end{array}$ & $\begin{array}{l}-0.074 * * * \\
(0.024)\end{array}$ & $\begin{array}{c}-0.074 * * * \\
(0.024)\end{array}$ \\
\hline s Debt ratio & & & & $\begin{array}{c}-0.001 \\
(0.021)\end{array}$ & $\begin{array}{c}-0.012 \\
(0.024)\end{array}$ & $\begin{array}{c}-0.013 \\
(0.024)\end{array}$ \\
\hline s Profitability & & & & $\begin{array}{l}0.069 * * * \\
(0.022)\end{array}$ & $\begin{array}{l}0.079 * * * \\
(0.026)\end{array}$ & $\begin{array}{l}0.079 * * * \\
(0.026)\end{array}$ \\
\hline s Excess return & & & & $\begin{array}{l}0.102 * * * \\
(0.018)\end{array}$ & $\begin{array}{l}0.097 * * * \\
(0.020)\end{array}$ & $\begin{array}{l}0.097 * * * \\
(0.020)\end{array}$ \\
\hline s Tangibility & & & & $\begin{array}{c}-0.024 \\
(0.020)\end{array}$ & $\begin{array}{c}-0.019 \\
(0.023)\end{array}$ & $\begin{array}{c}-0.019 \\
(0.023)\end{array}$ \\
\hline s Size & & & & $\begin{array}{l}0.100^{* * *} \\
(0.028)\end{array}$ & $\begin{array}{l}0.139 * * * \\
(0.034)\end{array}$ & $\begin{array}{l}0.139 * * * \\
(0.033)\end{array}$ \\
\hline s Focus & & & & $\begin{array}{l}0.135^{* * *} \\
(0.021)\end{array}$ & $\begin{array}{l}0.114^{* * * *} \\
(0.024)\end{array}$ & $\begin{array}{l}0.114^{* * * *} \\
(0.024)\end{array}$ \\
\hline s Size similarity & & & & $\begin{array}{l}0.173 * * * \\
(0.028)\end{array}$ & $\begin{array}{l}0.202^{* * * *} \\
(0.032)\end{array}$ & $\begin{array}{l}0.202^{* * * *} \\
(0.032)\end{array}$ \\
\hline s MTB similarity & & & & $\begin{array}{l}0.136^{* * *} \\
(0.022)\end{array}$ & $\begin{array}{l}0.144 * * * \\
(0.025)\end{array}$ & $\begin{array}{l}0.144^{* * *} \\
(0.025)\end{array}$ \\
\hline Product similarity & & & & $\begin{array}{l}0.141^{* * *} \\
(0.027)\end{array}$ & $\begin{array}{l}0.144 * * * \\
(0.037)\end{array}$ & $\begin{array}{l}0.144 * * * \\
(0.030)\end{array}$ \\
\hline Industry concentration & & & & $\begin{array}{l}-0.345^{* * *} \\
(0.130)\end{array}$ & $\begin{array}{l}-0.523^{* * *} \\
(0.159)\end{array}$ & $\begin{array}{l}-0.523^{* * * *} \\
(0.155)\end{array}$ \\
\hline Takeover intensity & & & & $\begin{array}{l}2.264 * * * \\
(0.310)\end{array}$ & $\begin{array}{l}2.803 * * * \\
(0.345)\end{array}$ & $\begin{array}{l}2.804^{* * * *} \\
(0.345)\end{array}$ \\
\hline GDP growth & & & & $\begin{array}{l}7.335^{* * *} \\
(1.011)\end{array}$ & $\begin{array}{l}6.487 * * * \\
(1.187)\end{array}$ & $\begin{array}{l}6.486^{* * * *} \\
(1.178)\end{array}$ \\
\hline Constant & $\begin{array}{l}-2.661^{* * *} \\
(0.094)\end{array}$ & $\begin{array}{l}-2.662 * * * \\
(0.117)\end{array}$ & $\begin{array}{l}-2.651^{* * *} \\
(0.089)\end{array}$ & $\begin{array}{l}-4.207 * * * \\
(0.163)\end{array}$ & $\begin{array}{l}-3.811^{* * *} \\
(0.289)\end{array}$ & $\begin{array}{l}-3.811^{* * *} \\
(0.238)\end{array}$ \\
\hline Number of observations & 69,982 & 69,982 & 69,982 & 74,131 & 63,007 & 63,007 \\
\hline
\end{tabular}


Next, we investigate whether time-varying firm and market characteristics are responsible for the age effects we observe. We do so by adding the set of control variables that we discussed above to our regression specification. Regression 4 focuses on the various control variables and omits firm age. The estimates from the Prentice-Gloeckler model imply that takeover risk is lower for firms with better growth (s Sales growth), higher valuation (s MTB equity), and larger cash holdings (s Cash). Contrary to the hypothesis that takeover disciplines poorly performing firms, however, we find that takeover hazard is actually higher for firms with stronger operating performance (s Profitability) and stronger stock market performance (s Excess return). We are, however, controlling for other dimensions of profitability such as sales growth, which could explain this finding. The positive correlation with stock market performance is consistent with Baker and Kennedy (2002), who show that the stock of takeover targets performs particularly well in the year prior to takeover, an indication that market participants suspect the firm is in play. The fact that focus has a positive coefficient could mean that acquirers prefer pure players. In line with the "like-buys-like" hypothesis proposed by Rhodes-Kropf and Robinson (2008) and the finding of Hoberg and Phillips (2010) that mergers are more likely to occur between partners with similar products, the coefficients of the three similarity measures Product similarity, s Size similarity, and s MTB similarity are all positive and highly significant. The positive coefficient of Takeover intensity is consistent with the notion that mergers occur in waves (see, e.g., Mitchell and Mulherin, 1996). As for the positive coefficient associated with stronger economic growth, it suggests that the reallocation of resources via merger is livelier during boom phases of the economy. Not surprisingly, that reallocation is also more vigorous in less concentrated and hence potentially more competitive industries. Size is positively related with takeover risk whereas leverage and asset tangibility are statistically zero.

Regressions 5 and 6 show that, when we include the control variables in the univariate regression specifications of the first two columns, firm age maintains its negative and significant coefficient, regardless of the assumed form of unobserved heterogeneity. The coefficient of age remains statistically unchanged. As it turns out, that coefficient remains the same also when we do not control for unobserved heterogeneity (not shown).

In unreported estimations, we find that hazard rates decline with age regardless of the functional form we choose for that relation. We use alternatively: $-1 /(1+$ Age $)$, the age metric proposed by Pastor and Veronesi (2003); Age and $\mathrm{Age}^{2}$; and the binary variable, b Old, that identifies firms older than the sample median in any given year. 


\subsection{COMPETING RISK REGRESSIONS}

As mentioned above, single destination models can produce biased estimates if the exit risks are competing. To prevent that we reassess the age-dependence of takeover risk in the context of competing risk regressions. We allow for the three exit routes from Table I. The dependent variable is therefore equal to 0 if the firm survives (the base outcome), 1 if it is taken over, 2 if it fails, and 3 if it exits for other reasons. The category "other reasons" is included for econometric purposes and is not reported separately in any of the following tables. The regression arguments are the same as in Table II, augmented, since we are extending the analysis to failure risk, by the two variables Naïve PD and 1/Volatility discussed in Section 2.2.

Table III shows the results. For comparison purposes, the first regression specification focuses on firm age and excludes all control variables. Models 2 and 3 then study the age-dependence of exit risk conditional on the various control variables and with different age measures. As one can see, switching from single destination models to competing risk regressions does not change the relation between firm age and takeover risk. The age coefficients are statistically identical to the ones from the single destination models. Therefore, competing exit risks do not seem to be of major concern for our investigation. For the same reason, neither is unobserved heterogeneity.

The coefficients of the control variables also remain unchanged. In particular, the coefficient of the standardized MTB equity variable is still negative and significant throughout. This suggests that firms that are priced at the upper end of the valuation spectrum in their industry, and therefore firms that tend to be perceived as being overpriced, are less likely to be taken over. Overpricing does not have to be a fact, it could simply be an opinion of financial analysts, business analysts, and investment bankers who are active in the M\&A market. Since the coefficient of age is always negative and significant in spite of controlling for MTB ratios, the evidence implies that perceived overpricing is not the reason for the negative age-dependence of takeover hazard. None of the two new control variables, Naïve PD and $1 /$ Volatility, has coefficients that are different from zero at conventional levels of significance.

Appendix B conducts extensive tests of whether individual omitted variables or different coefficients of the control variables between young and mature firms could be responsible for the negative age-dependence of takeover hazard. We examine firm size, potential imbalances between growth opportunities and available resources, inefficient investment policies, age of managers and directors, management talent, and industry age. None of them can explain the dependence in question. 
Table III. Company age and competing exit risks

The table estimates pooled multinomial logit regressions with standard errors corrected for heteroskedasticity and firm clustering. We distinguish between takeover and failure hazard as well as other exit reasons (not reported). Model 1 is univariate. In Models 2 and 3, we add the control variables and use two different measures of age: $\ln (A g e)$ in Regression 2; and the old-firm dummy ( $b$ Old) in Regression 3. Standard errors are clustered at the firm level and reported in parentheses. Variable definitions are in Table AI. The symbols ***,**, and $*$ indicate significance at the $1 \%, 5 \%$, and $10 \%$ two-tailed level, respectively.

\begin{tabular}{|c|c|c|c|c|c|c|}
\hline & \multicolumn{2}{|c|}{ M-Logit 1} & \multicolumn{2}{|c|}{ M-Logit 2} & \multicolumn{2}{|c|}{ M-Logit 3} \\
\hline & Takeover & Failure & Takeover & Failure & Takeover & Failure \\
\hline $\ln ($ Age $)$ & $\begin{array}{c}-0.207 * * * \\
(0.031)\end{array}$ & $\begin{array}{c}-0.739 * * * \\
(0.044)\end{array}$ & $\begin{array}{c}-0.148 * * * \\
(0.037)\end{array}$ & $\begin{array}{c}-0.205^{* * *} \\
(0.053)\end{array}$ & & \\
\hline b Old & & & & & $\begin{array}{c}-0.123^{* *} \\
(0.050)\end{array}$ & $\begin{array}{c}-0.159^{* *} \\
(0.073)\end{array}$ \\
\hline Naïve PD & & & $\begin{array}{c}-0.202 \\
(0.145)\end{array}$ & $\begin{array}{l}2.191 * * * \\
(0.139)\end{array}$ & $\begin{array}{c}-0.188 \\
(0.144)\end{array}$ & $\begin{array}{l}2.211^{* * *} \\
(0.138)\end{array}$ \\
\hline s Size & & & $\begin{array}{l}0.085^{* *} \\
(0.038)\end{array}$ & $\begin{array}{c}-0.757^{* * *} \\
(0.059)\end{array}$ & $\begin{array}{c}0.073^{*} \\
(0.038)\end{array}$ & $\begin{array}{c}-0.774 * * * \\
(0.058)\end{array}$ \\
\hline s Debt ratio & & & $\begin{array}{c}0.043 \\
(0.029)\end{array}$ & $\begin{array}{c}0.076^{*} \\
(0.039)\end{array}$ & $\begin{array}{c}0.044 \\
(0.029)\end{array}$ & $\begin{array}{c}0.072 * \\
(0.040)\end{array}$ \\
\hline s $1 /$ Volatility & & & $\begin{array}{c}-0.013 \\
(0.032)\end{array}$ & $\begin{array}{l}-0.345^{* * * *} \\
(0.064)\end{array}$ & $\begin{array}{c}-0.022 \\
(0.032)\end{array}$ & $\begin{array}{c}-0.348^{* * *} \\
(0.063)\end{array}$ \\
\hline s Excess return & & & $\begin{array}{l}0.103^{* * * *} \\
(0.021)\end{array}$ & $\begin{array}{c}-0.317 * * * \\
(0.040)\end{array}$ & $\begin{array}{l}0.102^{* * *} \\
(0.021)\end{array}$ & $\begin{array}{c}-0.317^{* * *} \\
(0.040)\end{array}$ \\
\hline s Profitability & & & $\begin{array}{c}0.039 \\
(0.029)\end{array}$ & $\begin{array}{c}-0.503 * * * \\
(0.030)\end{array}$ & $\begin{array}{c}0.038 \\
(0.029)\end{array}$ & $\begin{array}{c}-0.509 * * * \\
(0.030)\end{array}$ \\
\hline s Sales growth & & & $\begin{array}{c}-0.115^{* * *} \\
(0.027)\end{array}$ & $\begin{array}{c}-0.118^{* * * *} \\
(0.032)\end{array}$ & $\begin{array}{c}-0.109^{* * * *} \\
(0.027)\end{array}$ & $\begin{array}{c}-0.110^{* * *} \\
(0.032)\end{array}$ \\
\hline s MTB equity & & & $\begin{array}{c}-0.070^{* *} \\
(0.031)\end{array}$ & $\begin{array}{c}0.011 \\
(0.026)\end{array}$ & $\begin{array}{c}-0.068^{* *} \\
(0.031)\end{array}$ & $\begin{array}{c}0.015 \\
(0.026)\end{array}$ \\
\hline s Cash & & & $\begin{array}{c}-0.099^{* * * *} \\
(0.029)\end{array}$ & $\begin{array}{c}-0.274 * * * \\
(0.049)\end{array}$ & $\begin{array}{c}-0.096^{* * *} \\
(0.029)\end{array}$ & $\begin{array}{c}-0.269^{* * *} \\
(0.049)\end{array}$ \\
\hline s Tangibility & & & $\begin{array}{l}-0.016 \\
(0.025)\end{array}$ & $\begin{array}{c}-0.028 \\
(0.034)\end{array}$ & $\begin{array}{c}-0.016 \\
(0.025)\end{array}$ & $\begin{array}{c}-0.026 \\
(0.034)\end{array}$ \\
\hline s Focus & & & $\begin{array}{l}0.109 * * * \\
(0.028)\end{array}$ & $\begin{array}{c}0.031 \\
(0.039)\end{array}$ & $\begin{array}{l}0.115^{* * *} \\
(0.028)\end{array}$ & $\begin{array}{c}0.037 \\
(0.039)\end{array}$ \\
\hline s Size similarity & & & $\begin{array}{l}0.166^{* * * *} \\
(0.036)\end{array}$ & $\begin{array}{c}0.065 \\
(0.078)\end{array}$ & $\begin{array}{l}0.166^{* * * *} \\
(0.036)\end{array}$ & $\begin{array}{c}0.063 \\
(0.078)\end{array}$ \\
\hline s MTB similarity & & & $\begin{array}{l}0.113^{* * * *} \\
(0.028)\end{array}$ & $\begin{array}{c}-0.302 * * * \\
(0.034)\end{array}$ & $\begin{array}{l}0.112^{* * *} \\
(0.028)\end{array}$ & $\begin{array}{c}-0.305^{* * *} \\
(0.034)\end{array}$ \\
\hline Product similarity & & & $\begin{array}{l}0.176^{* * *} \\
(0.035)\end{array}$ & $\begin{array}{l}0.201 * * * \\
(0.053)\end{array}$ & $\begin{array}{l}0.193^{* * *} \\
(0.035)\end{array}$ & $\begin{array}{l}0.217 * * * \\
(0.052)\end{array}$ \\
\hline Industry concentration & & & $\begin{array}{l}-0.443 * * * \\
(0.171)\end{array}$ & $\begin{array}{c}-0.248 \\
(0.249)\end{array}$ & $\begin{array}{c}-0.466^{* * *} \\
(0.172)\end{array}$ & $\begin{array}{c}-0.274 \\
(0.250)\end{array}$ \\
\hline Takeover intensity & & & $\begin{array}{l}2.799 * * * \\
(0.365)\end{array}$ & $\begin{array}{c}0.592 \\
(0.674)\end{array}$ & $\begin{array}{l}2.806^{* * * *} \\
(0.362)\end{array}$ & $\begin{array}{c}0.590 \\
(0.669)\end{array}$ \\
\hline GDP growth & & & $\begin{array}{l}4.068^{* * *} \\
(1.440)\end{array}$ & $\begin{array}{c}-6.490 * * * \\
(1.960)\end{array}$ & $\begin{array}{l}4.103^{* * *} \\
(1.426)\end{array}$ & $\begin{array}{c}-6.239 * * * \\
(1.942)\end{array}$ \\
\hline
\end{tabular}


Table III. Continued

\begin{tabular}{|c|c|c|c|c|c|c|}
\hline & \multicolumn{2}{|c|}{ M-Logit 1} & \multicolumn{2}{|c|}{ M-Logit 2} & \multicolumn{2}{|c|}{ M-Logit 3} \\
\hline & Takeover & Failure & Takeover & Failure & Takeover & Failure \\
\hline Constant & $\begin{array}{l}-2.490^{* * *} \\
(0.103)\end{array}$ & $\begin{array}{l}-1.461^{* * * *} \\
(0.134)\end{array}$ & $\begin{array}{l}-3.844^{* * *} \\
(0.267)\end{array}$ & $\begin{array}{l}-5.539^{* * * *} \\
(0.386)\end{array}$ & $\begin{array}{l}-4.357^{* * *} \\
(0.218)\end{array}$ & $\begin{array}{l}-6.213^{* * *} \\
(0.324)\end{array}$ \\
\hline Observations & \multicolumn{2}{|c|}{53,107} & \multicolumn{2}{|c|}{53,107} & \multicolumn{2}{|c|}{53,107} \\
\hline Pseudo $R^{2}$ & \multicolumn{2}{|c|}{0.008} & \multicolumn{2}{|c|}{0.196} & \multicolumn{2}{|c|}{0.196} \\
\hline
\end{tabular}

Table $I V$. The economic impact of company age on takeover exit hazard

The table shows predicted takeover hazards from Model 2 of Table III. All variables except for $\ln$ (Age) are kept at their average value. The first line of the table shows predicted takeover hazard at incorporation age $5(\ln ($ Age $)=1.6094)$. The second line of the table shows predicted takeover hazard at incorporation age $25(\ln ($ Age $)=3.2189)$.

Takeover hazard

\begin{tabular}{ll} 
Age $=5$ & $4.79 \%$ \\
Age $=25$ & $3.86 \%$ \\
Difference & $3.86-4.79=-0.93 \%$ \\
Standard error of difference & $0.30 \%$ \\
Left-hand side interval limit & $-0.93-2 \times 0.30=-1.53 \%$ \\
\hline
\end{tabular}

\subsection{THE ECONOMIC IMPACT OF AGE ON SURVIVAL}

We can use the coefficient estimates of Model 2 in Table III to predict the marginal contribution of age to takeover hazard and assess the economic significance of that relation. Table IV performs the analysis. All variables except for $\ln ($ Age $)$ are kept at their average sample value. The first line of the table shows predicted takeover hazards at age $5(\ln ($ Age $)=1.6094)$. The second line shows predicted takeover hazards at the median age of 25 $(\ln ($ Age $)=3.2189)$. The average difference is $-0.93 \%$ points. This represents a $19 \%$ reduction in takeover hazard. The lower bound on the $95 \%$ confidence interval corresponds to a relative decline of $32 \%$ in takeover hazard. Hence, the effect of company age appears to be economically palpable. 


\subsection{SEARCH COSTS AS A POSSIBLE EXPLANATION}

A possible interpretation of the negative age-dependence of takeover risk is that mature firms have fewer potential merger partners. ${ }^{2}$ Searching for merger partners is costly, which could induce firms to search only a part of the universe of potential targets each year. Once a firm has been screened by a potential acquirer and dismissed as a suitable takeover candidate, it will not be reconsidered by that potential acquirer in the future. Older firms could therefore face smaller takeover odds simply because they randomly passed the screening by potential acquirers and face a progressively smaller residual pool of potential acquirers. The problem with this interpretation is that, as we saw, the number of new entries and exits of listed firms every year is substantial, on average. Hence, the pool of potential merger partners does not necessarily decline. Moreover, the observed negative age-dependence of takeover hazard is conditional on, and therefore orthogonal to the standard proxies for merger synergies. Thus, arguments that ultimately rely on those synergies do not seem to be able to explain the takeover hazard pattern in question.

For a more direct test, we look for measures of search costs. RhodesKropf and Robinson (2008) argue that search frictions are lower when liquidity in the capital markets and valuation levels are high. Following these authors, we use the commercial and industrial loan rates spread over the intended Federal funds rate as a proxy for market liquidity (C\&I spread), and a binary variable that identifies industries with historically high valuation levels as a proxy for industries with high valuation (b High valuation). Regression 1 of Table $\mathrm{V}$ adds these variables to the hazard model from Table III (M-Logit 2), our standard regression model. If search frictions were responsible for the negative sensitivity of takeover hazard to age, we would expect the coefficient of $\ln ($ Age) to decline in size. We find that the coefficient does indeed decline numerically from 0.148 to 0.129 . The change, however, is statistically zero. In untabulated regressions, we split the sample into high and low search cost periods according to our two proxies. The search-costs hypothesis would predict that the age effect is significantly lower at times of low search costs. However, the evidence does not support that prediction.

Another way to test the search-cost hypothesis is to distinguish between incorporation and listing age. As a result of better disclosure, the search process for takeover candidates should run its course only when the firm

$\overline{2}$ We are grateful to the referee for pointing out this interpretation of the evidence as well as its empirical test. 
Table $V$. A search-cost explanation of declining takeover hazard

The table extends the hazard Model 2 from Table III with measures of search costs. Regression 1 adds a proxy for market liquidity (C\&I spread) and a binary variable that identifies industries with high valuation (b High valuation). Regression 2 splits the firms' incorporation age into Age at listing and Listing age. Regression 3 includes all four additional variables at the same time. To preserve space, we do not report the coefficients of the control variables. Standard errors are clustered at the firm level and reported in parentheses. Variable definitions are in Table AI. The symbols $* * *$ and $* *$ indicate significance at the $1 \%$ and $5 \%$ two-tailed level, respectively.

Takeover hazard

(1)

$$
\begin{gathered}
-0.129 * * \\
(0.050) \\
0.614 * * * \\
(0.090) \\
-0.034 \\
(0.046)
\end{gathered}
$$

Age at listing

Listing age

Controls

Observations

Pseudo $R^{2}$
(2)

(3)

$\begin{array}{lccc}\text { b Old } & -0.129^{* *} & & \\ & (0.050) & & 0.615^{* * *} \\ \text { C\&I spread } & 0.614^{* * *} & & (0.092) \\ & (0.090) & & -0.027 \\ \text { b High valuation } & -0.034 & & (0.047) \\ & (0.046) & -0.003^{* *} & -0.003^{* *} \\ \text { Age at listing } & & (0.001) & (0.001) \\ & & -0.006^{* *} & -0.006^{* * *} \\ \text { Listing age } & & (0.002) & (0.002) \\ & & \text { Included } & \text { Included } \\ \text { Controls } & \text { Included } & 50,991 & 50,991 \\ \text { Observations } & 53,107 & 0.197 & 0.236 \\ \text { Pseudo } R^{2} & 0.235 & & \end{array}$

is publicly traded. As a consequence, incorporation age at listing should be unrelated with takeover hazard, whereas listing age should have a negative coefficient. According to Regression 2 of Table V, however, both age measures are negatively and significantly related with takeover risk, even though the coefficient of Listing age is numerically twice as large as the coefficient of Age at listing.

Overall, we therefore conclude that search-cost considerations might affect the probability of takeover but they seem unable to explain the negative age-dependence of takeover hazards.

\subsection{PRELIMINARY CONCLUSIONS}

Contrary to the initial expectations, we find a robust, statistically, and economically significant negative relation between firm age and takeover 
hazard, even after controlling for variables that other papers typically control for. A number of omitted variables could have caused this finding, but none of those we examine can explain the results. Our proxies for search costs cannot explain that relation either. If mature firms are comparatively less frequently involved in takeovers, it must ultimately be because their managers resist takeover or because they are comparatively costly to integrate. The rest of the paper is dedicated to testing these two hypotheses.

\section{Agency Problems and Declining Takeover Hazards}

Murphy (1997) and Hartzell, Ofek, and Yermack (2004), among others, document that the managers of target firms often lose their jobs in the aftermath of an acquisition. This prospect could be particularly threatening to the managers of older organizations, since the specialization process that these firms engage in (Loderer, Stulz, and Waelchli, 2014) could gradually reduce the value of their outside employment opportunities. If so, these managers will try to protect their quasi-rents and their internal career opportunities and enjoy a quieter life. They could do so by raising formal antitakeover barriers in the form of antitakeover provisions (ATPs) in the corporate charter and the corporate bylaws. ATPs make takeovers more expensive. $^{3}$

In what follows, we test whether that is the case. We also test whether mature firms are also less inclined to give their managers golden parachutes to encourage resistance against mergers and acquisitions.

\subsection{STRUCTURAL TAKEOVER DEFENSES IN OLDER FIRMS}

In principle, poison pills are the most formidable defense against takeover there is. Ever since the Delaware Supreme Court declared that pills are legitimate in 1985, almost all firms can adopt one very quickly even after a takeover bid has been made (Coates, 2000). Almost all companies therefore have a "shadow pill" readily available. In fact, almost all firms have charter provisions already in place authorizing blank check preferred stock, "the

\footnotetext{
3 The literature offers two reasons for the presence of ATPs. Both are predicated under the argument that they make takeovers more expensive. Under the first explanation, entrenched managers use them to fend off takeover (Comment and Schwert, 1995; Field and Karpoff, 2002; Core et al., 2006). According to the second explanation, ATPs confer management better bargaining power in merger negotiations (DeAngelo and Rice, 1983; Grossman and Hart, 1988).
} 
most common source of the securities used to create a poison pill," when they go public (Daines and Klausner, 2001, pp. 114-115). The shadow pill has made other defenses, such as fair price and supermajority vote provisions, unimportant (Coates, 2000). Yet it only takes a board decision to repeal a poison pill. Hence, to be an effective defense mechanism, a poison pill has to be accompanied by provisions that make it difficult for the bidding party to replace an incumbent board.

Following Daines and Klausner (2001), we therefore examine the presence of ATPs that can "delay a hostile bid above and beyond the ubiquitous pill" (p. 88): dual-class stock, staggered board, and inability of shareholders to act by written consent or to call a special meeting. We also examine the existence of actual poison pills and blank check preferred stock authorizations. Even though the shadow pill is ubiquitous, pills that are in place or ostensibly readily deployable could signal the intention to resist takeover. As mentioned, we also test whether mature firms are less likely to grant their managers golden parachutes. Data on governance provisions are from Risk Metrics.

\subsection{ANTITAKEOVER PROTECTION AT OLD AGE}

The first column in Table VI reports the popularity of the various antitakeover devices. Because Risk Metrics starts in 1990, the sample period is $1990-2009$. More than $90 \%$ of all firms have either a poison pill or a blank check preferred stock authorization in place. This is comparable with what Daines and Klausner (2001) report for their IPO firms. About $10 \%$ of the sample firms have multiple classes of stock, almost $60 \%$ have staggered boards (mostly in combination with pills or blank check preferred stock), and almost $40 \%$ have voting restrictions. Golden parachutes are granted in about $60 \%$ of the cases.

To test whether old firms are more likely to erect takeover barriers, we estimate logistic regressions in which the dependent variable equals 1 if a given firm adopts or removes a particular ATP in any given year, and equals 0 otherwise. Firms that have a specific provision in place are excluded from the analysis of adoptions; conversely, those that do not have a given provision are excluded from the analysis of removals. The regression arguments include the old firm dummy (b Old) and the set of control variables from Table II. To preserve space, we report only the coefficient of company age (second section of Table VI). Overall, we find little evidence that older firms beef up their structural takeover defenses. If anything, the opposite is true. Older firms are less likely to put poison pills in place, and more inclined to remove staggered boards 
Table VI. Company age and formal takeover defenses

The table investigates the relation between firm age and corporate ATPs. 'Company age and takeover defenses' examines the popularity of each provision (Sample mean). The governance variables are provided by IRRC on a bi- or triannual basis, starting in 1990 . To increase sample size, we interpolate those variables for missing sample years. 'Frequency of changes in antitakeover protection' lists the frequency of changes in governance provisions and investigates whether these changes are related with firm age, conditional on the control variables. The dependent variables in those regressions are binary variables that measure whether a given provision was added or removed in a given year, respectively. Firms that have a specific provision in place are excluded in the column labeled Adoptions; those that do not have it are excluded in the column labeled Removals. The control variables are obtained from Table II. Variable definitions are in Table AI. Standard errors are clustered at the firm level and reported in parentheses. The symbols ***,**, and * indicate significance at the $1 \%, 5 \%$, and $10 \%$ two-tailed level, respectively.

Company age and takeover defenses

\begin{tabular}{lc}
\hline & Sample mean \\
\hline b Dual class & 0.097 \\
b Staggered board & 0.565 \\
b Pill & 0.917 \\
b Staggered board and b Pill & 0.537 \\
b Voting restriction & 0.354 \\
b Golden parachute & 0.572 \\
\end{tabular}

Frequency of changes in antitakeover protection

\begin{tabular}{|c|c|c|c|c|c|}
\hline \multirow{2}{*}{ Provisions } & \multicolumn{2}{|c|}{ Adoptions } & \multicolumn{2}{|c|}{ Removals } & \multirow{2}{*}{ Firm Years } \\
\hline & Observations & $\begin{array}{l}\text { Coefficient } \\
b \text { Old }\end{array}$ & Observations & $\begin{array}{l}\text { Coefficient } \\
b \text { Old }\end{array}$ & \\
\hline Dual class & 21 & - & 44 & - & 12,060 \\
\hline Staggered board & 72 & -0.061 & 111 & $0.733 * *$ & 12,060 \\
\hline Pill & 57 & $-0.597 *$ & 32 & 0.661 & 12,060 \\
\hline Staggered board and Pill & 87 & -0.055 & 113 & $1.047 * * *$ & 12,060 \\
\hline Voting restriction & 396 & -0.040 & 248 & $-0.671 * * *$ & 12,039 \\
\hline Golden parachute & 674 & $-0.203^{*}$ & 424 & $-0.272 * *$ & 12,023 \\
\hline
\end{tabular}

and to dismantle the combination of staggered boards and poison pills. They also tend to eliminate voting restrictions. There is, however, some evidence of less frequent adoption of golden parachutes in older firms. Yet, overall, we conclude that there is little evidence that older firms boost their structural takeover defenses over time. 


\section{Declining Takeover Risk and the Integration Costs of Older Firms}

The remaining interpretation of the negative age-dependence of takeover hazard is that a takeover is not believed to create sufficient value to justify the subsequent integration costs. Holmstrom (1989) argues that mature firms primarily serve production and marketing goals. To pursue these goals, they rationally depend on incentive mechanisms and organizational rules and best practice that induce organizational rigidities. Since it takes time to implement and optimize these rules and arrangements, they will correlate with company age. And since they are difficult to unwind, they will make mature firms more costly to integrate into different organizations and therefore, all else the same, less likely to be acquired.

We conduct two tests of this integration costs hypothesis. First, we investigate whether adverse exogenous shocks to the expected merger benefits lead to a more negative age-dependence of takeover hazards. Second, and more important, we look for proxies for rigidities and test whether they explain the age effect we observe.

\subsection{EXOGENOUS ECONOMIC SHOCKS AND TAKEOVER RISK}

If old firms are unattractive merger partners because they are more costly to integrate, we would expect their merger appeal to be particularly low at times of industry distress. This prediction follows from a simple cost-benefit analysis of mergers. Whereas the expected benefits of a merger of two firms depend positively on business conditions, the integration costs associated with that transaction would seem to be more or less constant. At times of industry distress, deals that entail high integration costs should therefore become especially rare because the expected benefits are more likely to fall below the integration costs. If firm age is a proxy for integration costs, we would therefore expect that industry distress lowers the takeover risk of mature firms further. To find out, we replicate the competing exit risk models of Table III and test whether industry distress does indeed further reduce the takeover hazard of mature firms.

We follow Opler and Titman (1994) and Gopalan and Xie (2011), among others, and classify an industry as distressed if its median sales growth is negative and its median stock return is below $-30 \%$ in any given year. Industry distress is quite infrequent and occurs in approximately only $4 \%$ of all industry-years. Table VII shows the results of the analysis. The first regression specification extends the competing risk regression of Model 3 in Table III with a binary variable that identifies firm years in distressed industries, b Industry distress, and an interaction term of that variable 
Table VII. Takeover hazard, firm age, and exogenous adverse industry shocks

The table asks how industry distress affects exit risk at old age. As in Opler and Titman (1994) and Gopalan and Xie (2011), among others, an industry is assumed to be in distress if median sales growth is negative and median stock return is below $-30 \%$ in any given year. Distressed industries are identified with the binary variable bIndustry distress. Regression 1 of 'M-logit estimates' adds bIndustry distress as well as an interaction term with the old-firm dummy to the standard competing risk regression Model 3 from Table III. Regression 2 estimates the standard competing risk regression in the subsample of firms that operate in distressed industries. To preserve space, we do not report the coefficients of the control variables. Standard errors are clustered at the firm level and reported in parentheses. Variable definitions are in Table AI. 'Norton, Wang, and Ai (2004) interaction terms for Regression 1' re-estimates the interaction terms from Model 1 of 'M-logit estimates' using the procedure suggested by Norton, Wang, and Ai (2004). The symbols *** and $* *$ indicate significance at the $1 \%$ and $5 \%$ two-tailed level, respectively.

\begin{tabular}{|c|c|c|c|c|}
\hline \multicolumn{5}{|c|}{ M-logit estimates } \\
\hline & \multicolumn{2}{|c|}{ Full sample } & \multicolumn{2}{|c|}{ Distressed industries } \\
\hline & \multicolumn{2}{|c|}{ Regression 1} & \multicolumn{2}{|c|}{ Regression 2} \\
\hline & Takeover & Failure & Takeover & Failure \\
\hline b Old & $\begin{array}{c}-0.107 * * \\
(0.051)\end{array}$ & $\begin{array}{c}-0.223 * * * \\
(0.077)\end{array}$ & $\begin{array}{c}-0.995^{* * * *} \\
(0.364)\end{array}$ & $\begin{array}{l}0.835^{* * *} \\
(0.291)\end{array}$ \\
\hline b Industry distress & $\begin{array}{c}-0.004 \\
(0.178)\end{array}$ & $\begin{array}{c}0.302 \\
(0.188)\end{array}$ & & \\
\hline b Old $\times$ b Industry distress & $\begin{array}{c}-0.754 * * \\
(0.332)\end{array}$ & $\begin{array}{l}0.795^{* * * *} \\
(0.268)\end{array}$ & & \\
\hline Other controls & & & & \\
\hline Observations & & & & \\
\hline Pseudo $R^{2}$ & & & & \\
\hline
\end{tabular}

Norton, Wang, and Ai (2004) interaction terms for Regression 1

\begin{tabular}{lll}
\hline & Takeover hazard & Failure hazard \\
\hline Average interaction effect & -0.02 & 0.02 \\
Min; Max interaction effect & $-0.099 ;-0.003$ & $0.000 ; 0.196$ \\
Estimated $z$-statistics & & P-statistics of Interaction Effects after Logit \\
\hline
\end{tabular}


with the old-firm dummy, $b$ Old. Under this specification, the coefficient of $b$ Old remains negative and significant for both hazards. More important, however, the interaction term $\mathrm{b}$ Old $\times \mathrm{b}$ Industry distress has a negative and significant coefficient in the takeover regression, consistent with the prediction that hard times for the industry overall further reduce the takeover hazard of older firms. The implied takeover hazard of an older firm drops by $50 \%$ at times of industry distress (from $3.60 \%$ to $1.80 \%$ ), whereas that of a young firm is unaffected $(4.10 \%$ versus $4.11 \%)$. Note that industry distress per se does not seem to affect takeover risk. ${ }^{4}$ The estimation and interpretation of interaction terms in nonlinear models is not straightforward. For completeness, we therefore also follow the procedure suggested by Norton, Wang, and Ai (2004) and estimate a separate interaction effect for each observation using a logit specification. The second section of Table VII shows the results. The average interaction effect is the same as in the first section $(1.8 \%)$. Moreover, the estimated interaction effects are always negative and significant with confidence 0.9 or better. Therefore, we conclude that old age is indeed associated with lower takeover risk at times of industry distress.

In the second regression specification of the table's first section, we restrict our attention to firms in distressed industries. We therefore drop the $b$ Industry distress variable and its interaction term, and estimate the model for firms in distressed industries. The age coefficient is negative and significant in the case of takeover hazard. Furthermore, and consistent with the prediction of the integration costs hypothesis, it is significantly more negative than in normal times.

\subsection{FIRM AGE, RIGIDITIES, AND TAKEOVER RISK}

If higher merger integration costs of old firms are driven by the accumulation of rigidities over time, we should observe that mature firms show more symptoms of rigidity, that rigidities deter takeover, and that they explain at least part of the negative age-related decline in takeover hazard. To test these predictions, we identified four possible rigidity measures. Various firms, not only mature ones, have these characteristics. However, they should be typical of the average mature firm. What follows first discusses the rigidity proxies and then tests their impact on the relation between firm age and takeover risk.

4 The results remain qualitatively the same if we add interaction terms of all control variables with b Old. 


\section{2.a Rigidity measures}

The rigidities we focus on relate to the firm's cost structure, its investment policy, product portfolio, and organizational structure. The rationale for these rigidities is as follows (the proxies we use are described in Appendix A):

(1) Cost rigidities: Anderson, Banker, and Janakiraman (2003) report that overhead expenses are more sensitive to increases than to decreases in sales. The reason is the costs of reestablishing production capacity following a reduction. Firms are therefore reluctant to cut overhead when demand declines, because the decline could be only temporary. In our sample, a $1 \%$ decline in sales is associated with only a $0.5 \%$ decrease in overhead expenses. Anderson, Banker, and Janakiraman (2003) report similar numbers. If they are indeed inflexible, mature firms should be particularly unable to cut costs when demand declines.

(2) Investment rigidities: A rigid investment policy implies that firms fail to respond to positive NPV investment opportunities.

(3) Product portfolio rigidities: Hoberg, Phillips, and Prabhala (2014) provide measures of product fluidity based on the product description in the firms' $10-\mathrm{K}$. They show that the product mix of old firms is more stable than that of young firms. Our proxy for product rigidities is the negative value of the Hoberg, Phillips, and Prabhala (2014) fluidity measure.

(4) Organizational rigidities: Geographically dispersed organizations are more complex (Denis, Denis, and Yost, 2002; Bushman et al., 2004) and consequently more impervious to change. A binary variable that identifies firms with multinational activities is our proxy for organizational rigidities.

The first section of Table VIII reports summary statistics for the various rigidity measures, sorted by age quartiles. The numbers show that rigidities increase monotonically with age. The two columns on the right-hand side of the panel show this formally with mean comparison and proportion tests. Regardless of measure, old firms have significantly higher rigidity scores.

\section{2.b Rigidities and takeover risk}

To test whether rigidities are responsible for the negative age-dependence of takeover risk, we extend the standard hazard model from Table III (M-Logit 2) with our rigidity measures. The second section of Table VIII shows the results. As expected, the presence of rigidities lowers the takeover hazard. Individually, all four rigidity proxies have a statistically significant 
Table VIII. Firm age, rigidities, and takeover risk

The table investigates whether rigidities can explain the age effect on takeover hazard. 'Summary statistics' reports average rigidity scores sorted by age quartile and performs comparison tests. We report $z$-statistics from proportion tests for the binary rigidity measures (prefix -b) ant $t$-statistics from mean comparison tests for the continuous rigidity measure. 'Hazard model estimates' replicates the standard competing risk regression Model 3 from Table III for the subsample of firms with data on the rigidity measures. To save space, we do not report the coefficients of the control variables. Standard errors are clustered at the firm level and reported in parentheses. The symbols *** and ** indicate significance at the $1 \%$ and $5 \%$ two-tailed level, respectively.

\begin{tabular}{|c|c|c|c|c|c|c|}
\hline \multicolumn{7}{|c|}{ Summary statistics } \\
\hline & \multicolumn{4}{|c|}{ Age quartiles } & \multirow[b]{2}{*}{ Q4 versus Q1 } & \multirow{2}{*}{$\begin{array}{l}\text { (Q3\&4) versus } \\
(\mathrm{Q} 1 \& 2)\end{array}$} \\
\hline & Q1 & Q2 & Q3 & Q4 & & \\
\hline b Rigid costs & 0.191 & 0.196 & 0.197 & 0.210 & $3.96 * * *$ & $2.50 * *$ \\
\hline b Rigid investments & 0.275 & 0.361 & 0.402 & 0.405 & $23.37 * * *$ & $23.09 * * *$ \\
\hline Product stability & -8.296 & -7.521 & -6.267 & -5.045 & $61.19 * * *$ & $58.88 * * *$ \\
\hline b Multinational & 0.150 & 0.205 & 0.249 & 0.382 & $47.03 * * *$ & $39.59 * * *$ \\
\hline
\end{tabular}

Hazard model estimates

\begin{tabular}{|c|c|c|c|c|c|c|c|c|}
\hline & \multicolumn{8}{|c|}{ Takeover hazard } \\
\hline & (1) & (2) & (3) & (4) & (5) & (6) & (7) & (8) \\
\hline b Old & $\begin{array}{c}-0.207 * * * \\
(0.057)\end{array}$ & $\begin{array}{c}-0.166 * * * \\
(0.056)\end{array}$ & $\begin{array}{c}-0.093 \\
(0.069)\end{array}$ & $\begin{array}{c}-0.138 * * * \\
(0.052)\end{array}$ & $\begin{array}{l}-0.155^{* * *} \\
(0.053)\end{array}$ & $\begin{array}{c}-0.078 \\
(0.078)\end{array}$ & $\begin{array}{c}-0.080 \\
(0.053)\end{array}$ & $\begin{array}{c}-0.098 \\
(0.077)\end{array}$ \\
\hline b Rigid costs & $\begin{array}{l}-0.213^{* * * *} \\
(0.074)\end{array}$ & & & & & $\begin{array}{c}-0.216^{* *} \\
(0.105)\end{array}$ & $\begin{array}{l}-0.195 * * * \\
(0.074)\end{array}$ & \\
\hline b Rigid investments & & $\begin{array}{c}-0.119 * * \\
(0.054)\end{array}$ & & & & $\begin{array}{l}-0.214^{* * *} \\
(0.075)\end{array}$ & $\begin{array}{l}-0.169 * * * \\
(0.054)\end{array}$ & \\
\hline Product rigidities & & & $\begin{array}{c}-0.035^{* * *} \\
(0.013)\end{array}$ & & & $\begin{array}{l}-0.043^{* * *} \\
(0.014)\end{array}$ & & \\
\hline Product rigidities 2 & & & & $\begin{array}{c}-0.048 * * * \\
(0.012)\end{array}$ & & & $\begin{array}{l}-0.036^{* * * *} \\
(0.011)\end{array}$ & \\
\hline b Multinational & & & & & $\begin{array}{c}-0.126^{* *} \\
(0.063)\end{array}$ & $\begin{array}{c}-0.120 \\
(0.090)\end{array}$ & $\begin{array}{c}-0.138 * * \\
(0.063)\end{array}$ & \\
\hline Nondisclosure dummies & & & & Included & & & Included & \\
\hline Controls & Included & Included & Included & Included & Included & Included & Included & Included \\
\hline$N$ & 42,775 & 44,744 & 22,099 & 51,101 & 46,591 & 17,562 & 51,101 & 17,562 \\
\hline Pseudo $R^{2}$ & 0.203 & 0.204 & 0.280 & 0.199 & 0.229 & 0.298 & 0.233 & 0.296 \\
\hline
\end{tabular}

coefficient (Regressions 1-5). However, firm age (b Old) maintains its negative and significant coefficient in most regressions. The exception is the regression involving product rigidities (Regression 3), where firm age is only marginally significant in a one-sided test against zero. A potential 
concern with this regression is the number of observations because data from Hoberg, Phillips, and Prabhala (2014) are available only for the sample period 1996-2009. To address this concern, we proceed as follows. Hoberg, Phillips, and Prabhala (2014) report that product fluidity is highly correlated with industry concentration, firm value, risk, profitability, and research and development expenditures. We therefore regress Product rigidities on these variables as well as industry-fixed effects, and use the coefficient estimates from that regression to generate fitted values for the missing sample years. With an adjusted $R^{2}$ of 0.46 , the explanatory power of the regression is sizable. Based on this information, we then define an alternative rigidity measure, Product rigidities 2 , which equals the fitted values from the regression if data for Product rigidities are unavailable, otherwise it equals the value of Product rigidities. Regression 4 of the second section adds this variable to the hazard model, along with a binary variable that flags fitted values (nondisclosure dummy). The coefficient of Product rigidities 2 is statistically the same as that of Product rigidities in Regression 3 for the limited sample. With this specification, the coefficient of age is still negative and significant. It is, however, numerically smaller than in the regressions involving the other rigidity proxies.

The rigidity proxies are therefore unable, individually, to fully explain the age effect we observe. To examine their joint effect, we include them all at the same time. Regression 6 shows the results for the subsample of 17,562 observations with all the available rigidity data. In that regression, all coefficients of the rigidity proxies remain negative and, with the exception of b Multinational, significant with confidence 0.95 or better. Firm age is statistically zero. Firm age remains insignificant also in Regression 7, where we use Product rigidities 2 as our proxy for product rigidities to increase the sample size. The rigidity proxies maintain negative and significant coefficients similar to those observed in the individual regressions. In this regression, the coefficient of b Old drops by more than half in size compared with the regression without rigidity proxies (not shown in a separate table) and is also statistically insignificantly different from zero. Hence, jointly, we conclude that the four rigidities can explain the negative relation between takeover hazard and company age.

\subsection{DISCUSSION}

Since firms gradually run out of valuable growth opportunities when they get older (Loderer, Stulz, and Waelchli, 2014), one would expect them to engage more frequently in restructuring activities. It could be that mature firms choose forms of restructuring other than merger. 
A detailed analysis of this question goes beyond the scope of this article. However, we can use the evidence provided in extant papers to find a preliminary answer.

Older firms could reposition themselves strategically by acquiring rather than merging with other firms. The evidence in Arikan and Stulz (2013), however, is inconsistent with the prediction that acquisition frequency increases with company age. According to their results, the acquisition rate is a $\mathrm{u}$-shaped function of firm age and there is no difference between young and old firms in terms of acquisition frequency. Moreover, it is firms with better growth opportunities that are more likely to make acquisitions irrespective of their lifecycle stage.

Mature firms could also restructure by disposing of core assets. Berchtold, Loderer, and Waelchli (2014) find that both the probability of asset sales as well as the size of the divested assets do indeed increase with firm age. Their evidence also shows, however, that mature firms are more likely to dispose of assets which are not part of their core activities and which have a higher-valued use under different management. Moreover, mature firms do not use the divestiture proceeds to acquire other firms or assets, or to fund their capital expenditures or their R\&D effort. Instead, they pay the money out to debtholders and shareholders. Hence, this evidence combined with the results in Loderer, Stulz, and Waelchli (2014) that mature firms also invest less and engage less in R\&D to begin with, does not support the hypothesis that older firms restructure more frequently to revitalize their growth opportunities.

\section{Firm Age and Financial Failure Hazard}

Our econometric approach controls for competing risks. Hence, our results provide insights also into the age-dependence of financial failure hazard. As mentioned in Section 1, the existing literature reports inconclusive results in this respect. The results in Table III indicate that the hazard of financial failure actually falls significantly with firm age in spite of controlling for various drivers of failure risk. As mentioned in Section 1, this effect could reflect learning by investors, lenders, and the firm, or local politics. Combined with the results for takeover hazard, the decline in failure hazard implies that life expectancy increases with firm age.

Interestingly, firm age significantly accelerates the financial failure hazard at times of industry distress (Table VII). Since old firms are very good at managing assets in place (Loderer, Stulz, and Waelchli, 2014), this 
finding suggests that they are particularly exposed to industry-wide threats that devalue those assets. The effect is sizeable. The model implied conditional failure hazard of an older firm increases from $1.72 \%$ to $4.01 \%$ if the industry enters distress - an increase by a factor of 2.3. In contrast, the implied failure hazard of a younger firm increases only by a factor of 1.3 , namely from $2.17 \%$ to $2.84 \%$. The higher failure rate of mature firms at times of industry distress could explain the existence of a value premium. ${ }^{5}$

\section{Conclusions}

We motivated the article with the question of what happens to firms over time in view of the fact that they run out of growth opportunities and experience a steady decline in profitability. We focused on takeover hazard, their main exit risk. The evidence shows that takeover hazard diminishes as firms get older, an effect that is not only significant, but also economically sizable.

We investigated possible reasons for this decline. The explanation that survives the test of the data is that, over time, firms focus on what they do best and thereby assume characteristics that are costly to unwind. This lack of appeal gets compounded, we find, when exogenous, industry-wide shocks reduce the potential benefits from merging with older firms.

Other explanations of the evidence are inconsistent with the data. That includes an agency interpretation, namely that managers want to keep their firms independent or want to live an easy life. We do not find any evidence that older firms actively resist takeover.

In conclusion, not only do older firms run out of profitable investment opportunities, they become unattractive M\&A investment opportunities themselves. They are also less likely to fail. The "perennial gale of creative destruction" that sweeps over the economy (Schumpeter, 1975) seems to abate when it comes to mature companies, except in the case of financial failure at times of industry-wide distress.

5 We are grateful to the referee for pointing this out. 


\section{Appendix A}

\section{Table AI. Variable definitions}

In the regressions, all firm-specific variables, except for company age and Merton model's "naïve" default probability, are standardized by industry and year. Standardized variables are then denoted with the prefix s-. All regression arguments are lagged by 1 year. Binary variables have the prefix b-.

\begin{tabular}{ll}
\hline Variable Definition \\
\hline
\end{tabular}

Firm age

Age

b Old

Listing age

Control variables

Cash

Debt ratio

Excess return

Focus

GDP growth

Industry concentration

MTB equity

MTB similarity
Age is computed as one plus the difference between the year under investigation and the firm's year of incorporation.

A dummy variable that identifies firms older than the median in any given year.

Listing age is computed as one plus the difference between the year under investigation and the firm's year of listing.

The firm's cash and short-term investments (che) divided by the book value of its total assets (at - ceq + csho*prcc_f $-t x d b)$.

The ratio of the book value of debt to the market value of the firm's assets.

The firm's market-adjusted annual stock return. The market is the CRSP value-weighted NYSE/AMEX index.

The Herfindahl index, $H_{\mathrm{E}}$, captures the degree of specialization based on the sales in the firm's different segments, as reported on the COMPUSTAT Segment tapes:

$$
H_{\mathrm{E}}=\sum_{i=1}^{N} p_{i}^{2},
$$

where $N$ is the number of segments, the subscript $i$ identifies the segments, and $p_{i}$ is the fraction of the firm's total sales in the segment in question. Focus is a binary variable equal to 1 if the firm's Herfindahl index is 1 , otherwise it equals 0 .

The relative change in the US gross domestic product. The data are from the Bureau of Economic Analysis of the US Department of Commerce.

We follow Giroud and Mueller (2010), among many others, and measure the lack of competition of the firm's industry (three-digit SIC) with a Herfindahl index, $H_{\mathrm{E}}$ :

$$
H_{\mathrm{E}}=\sum_{i=1}^{N} s_{i}^{2},
$$

where $N$ is the number of firms in the same three-digit SIC industry, the subscript $i$ identifies the firms, and $s_{i}$ is the firms' market share based on sales (sale). The higher the index, the less competitive the industry becomes. To correct for potential misclassification, we drop the top $2.5 \%$ of the firm-years at the right tail of the distribution (Giroud and Mueller, 2010).

The firm's market value of equity divided by its book value of equity (ceq).

The number of industry peers with similar MTB valuation, divided by the total number of peers in the industry. We standardize MTB equity by industry and year (s MTB equity) and assume similar 
Table AI. Continued

Variable
Definition
market capitalization if s MTB equity of a peer does not deviate
from the firm's s MTB equity by more than 0.25.
The "naïve" default probability implied by Merton's (1974) model (see
Bharath and Shumway, 2008).
The log of the total product similarity measure (TNIC3TSIMM) from
Hoberg and Phillips (2010). The data are available for the sample
period 1996-2009. We regress Product similarity on MTB similarity,
Product similarity
effects and use the resulting coefficients to predict Product similarity
for the sample period before 1996.
Net income (ni) divided by book value total assets (ta).
The ratio of the firm's current sales (sale) divided by the sales of the
previous year minus 1. Sales figures are expressed in 2009 dollars.
The log of the market value of the firm's assets (at- ceq + csho*prcc f
- txdb).
The number of industry peers with similar market capitalization,
divided by the total number of peers in the industry. We standardize
the market value of equity by industry and year (s MVE) and
assume similar market capitalization if s MVE of a peer does not
Profitability
deviate from the firm's s MVE by more than 0.15.
The number of other firms in the same three-digit SIC industry that
Size
delist due to takeover, divided by the number of other firms in that
industry.
The firm's property, plant, and equipment (ppent) divided by Size.
The annualized standard deviation of the firm's monthly stock return.
We calculate volatility over a 5 -year window. The data are from the
monthly CRSP tapes.

b High valuation

Binary variable that identifies industries with a median equity marketto-book ratio that is higher than the average of the historical median equity-market-to-book ratio over the preceeding 5 years.

\section{C\&I Spread}

Antitakeover protection

b Dual class

b Golden parachute

b Pill

b Staggered board

b Voting restrictions

Integration costs of mergers

Industry distress

The commercial and industrial loan rates spreads over the intended federal funds rate. The data are from the Boards of Governors of the Federal Reserve System.

Binary variable that identifies firms with multiple classes of stock outstanding.

Binary variable that identifies firms with golden parachutes.

Binary variable that identifies firms that have a poison pill or a blank check preferred stock authorization.

Binary variable that identifies firms with classified boards.

Binary variable that identifies firms with restrictions on shareholders to vote by written consent or to call a special meeting.

Binary variable that identifies industries with negative median sales growth and median stock returns below $-30 \%$ in any given year.

b Rigid costs

In our sample, a $1 \%$ decline in sales is associated with only a $0.5 \%$ decrease in overhead expenses. Anderson, Banker, and Janakiraman (2003) report very similar numbers. We assume a firm has rigid costs 
Table AI. Continued

\begin{tabular}{ll}
\hline Variable & Definition \\
\hline & if its overhead expenses (expressed in 2009 dollars) drop by less than \\
& $0.5 \%$ in reaction to a $1 \%$ decrease in real sales. \\
b Rigid investments & Binary variable that identifies firms that fail to respond to a positive \\
investment signal to the industry. We assume a three-digit SIC & industry $i$ receives a positive signal if the median Tobin's $q$ of \\
another industry $j$ within the same SIC division increases by more \\
than $20 \%$ points relative to the median change in Tobin's $q$ of \\
industry $i$. Failure to respond to that signal means that the firm's \\
investment intensity (Capex + R\&D, normalized by lagged book \\
assets) falls behind the industry average. \\
The negative value of the firm's fluidity measure according to Hoberg, \\
Phillips, and Prabhala (2014). \\
The fraction of pretax income that comes from foreign operations. \\
Binary variable that identifies firms with Geographic dispersion $\neq 0$. \\
Product rigidities
\end{tabular}

\section{Table AII. Descriptive statistics}

The table provides descriptive statistics for the variables of relevance in the analysis. All control variables are winsorized at the 5th and 95th percentile of their pooled distribution across all firm-years. Variable definitions are in Table AI.

\begin{tabular}{lrrrrrr}
\hline & Mean & Median & \multicolumn{1}{c}{ Min } & Max & Stev & $N$ \\
\hline Company age & & & & & & \\
Listing age & 17.5 & 13.0 & 5.0 & 85.0 & 13.91 & 83,790 \\
Incorporation age & 34.4 & 25.0 & 5.0 & 193.0 & 26.01 & 69,982 \\
Age at listing & 16.4 & 9.0 & 19.9 & 1.0 & 156.0 & 7,590 \\
Control variables & & & & & & \\
Cash & 0.153 & 0.074 & 0.000 & 0.840 & 0.187 & 83,787 \\
Debt ratio & 0.192 & 0.147 & 0.000 & 0.727 & 0.184 & 83,532 \\
Excess return & 0.033 & -0.113 & -0.977 & 4.314 & 0.772 & 82,589 \\
Focus & 0.836 & 1.000 & 0.245 & 1.000 & 0.241 & 83,790 \\
GDP growth & 0.029 & 0.032 & -0.026 & 0.072 & 0.019 & 83,790 \\
Industry concentration & 0.207 & 0.161 & 0.029 & 0.965 & 0.157 & 81,280 \\
MTB equity & 2.475 & 1.627 & -9.006 & 24.042 & 3.736 & 83,787 \\
MTB similarity & 0.475 & 0.500 & 0.000 & 1.000 & 0.273 & 83,787 \\
Naïve PD & 0.092 & 0.000 & 0.000 & 0.905 & 0.204 & 70,540 \\
Product similarity & 297.836 & 188.090 & 62.477 & $3,589.867$ & 342.383 & 82,115 \\
Profitability & -0.010 & 0.039 & -1.056 & 0.364 & 0.207 & 82,408 \\
Sales growth & 0.098 & 0.040 & -0.705 & 2.638 & 0.415 & 82,894 \\
Size & $2,076.478$ & 236.119 & 4.499 & $44,174.280$ & $6,101.449$ & 83,790 \\
Size similarity & 0.588 & 0.727 & 0.000 & 1.000 & 0.335 & 83,790 \\
Takeover intensity & 0.042 & 0.031 & 0.000 & 1.000 & 0.053 & 83,238 \\
Tangibility & 0.297 & 0.243 & 0.009 & 0.895 & 0.223 & 83,725 \\
Volatility & 0.152 & 0.140 & 0.050 & 0.362 & 0.066 & 81,874 \\
\hline & & & & & & \\
\hline
\end{tabular}


Table AIII. Alternative interpretations of the age effect on takeover hazard

The table investigates alternative interpretations of the effect of company age on takeover hazard. Each row in the table reports coefficient estimates for the standard competing risk model of Table III (M-Logit 3) when adding the variable listed in the first column to the control variables along with an interaction term of $b$ Old with that variable. The results are statistically and economically the same when we alternatively estimate interaction effects using the procedure suggested by Norton, Wang, and Ai (2004). For reading convenience, we show only the coefficient of firm age, the coefficient of the variable in question, and the coefficient of the interaction term. Each section tests a different explanation for the negative time dependence of takeover hazard. The first section investigates the importance of firm size. The second section focuses on potential imbalances between growth and available resources. The third section examines the potential dissipation of resources. The fourth section investigates the relevance of management age. Finally, the fifth section inquires into the role of industry age. Standard errors are clustered at the firm level and reported in parentheses. Variable definitions are in Table AI. The symbols ***,**, and * indicate significance at the $1 \%, 5 \%$, and $10 \%$ two-tailed level, respectively.

\begin{tabular}{|c|c|c|c|c|}
\hline & $\begin{array}{l}\text { b Old } \\
\text { (1) }\end{array}$ & $\begin{array}{l}\text { Row variable } \\
\text { (2) }\end{array}$ & $\begin{array}{l}\text { Interaction } \\
(3)=(1) \text { and (2) }\end{array}$ & Controls \\
\hline \multicolumn{5}{|l|}{ Firm size } \\
\hline s Size & $\begin{array}{l}-0.182 * * * \\
(0.050)\end{array}$ & $\begin{array}{l}0.211 * * * \\
(0.045)\end{array}$ & $\begin{array}{l}-0.288 * * * \\
(0.050)\end{array}$ & Included \\
\hline \multicolumn{5}{|l|}{ Growth-resource imbalance } \\
\hline b Growth-resource imbalance & $\begin{array}{l}-0.186^{* * *} \\
(0.061)\end{array}$ & $\begin{array}{c}0.061 \\
(0.064)\end{array}$ & $\begin{array}{c}0.015 \\
(0.096)\end{array}$ & Included \\
\hline \multicolumn{5}{|l|}{ Dissipation of resources } \\
\hline b High R\&D and b Low growth & $\begin{array}{l}-0.169^{* * *} \\
(0.052)\end{array}$ & $\begin{array}{l}-0.064 \\
(0.110)\end{array}$ & $\begin{array}{l}-0.206 \\
(0.182)\end{array}$ & Included \\
\hline b High capex and b Low growth & $\begin{array}{l}-0.135^{* *} \\
(0.058)\end{array}$ & $\begin{array}{c}0.027 \\
(0.072)\end{array}$ & $\begin{array}{l}-0.231 * * \\
(0.105)\end{array}$ & Included \\
\hline \multicolumn{5}{|l|}{ Management team } \\
\hline b Old board & $\begin{array}{l}-0.429^{* *} \\
(0.203)\end{array}$ & $\begin{array}{l}-0.496^{* *} \\
(0.250)\end{array}$ & $\begin{array}{c}0.353 \\
(0.322)\end{array}$ & Included \\
\hline b Old CEO & $\begin{array}{c}-0.262^{*} \\
(0.149)\end{array}$ & $\begin{array}{c}0.065 \\
(0.163)\end{array}$ & $\begin{array}{l}-0.174 \\
(0.215)\end{array}$ & Included \\
\hline \multicolumn{5}{|l|}{ Industry age } \\
\hline b Old industry & $\begin{array}{l}-0.221 * * * \\
(0.069)\end{array}$ & $\begin{array}{l}-0.068 \\
(0.070)\end{array}$ & $\begin{array}{c}0.096 \\
(0.098)\end{array}$ & Included \\
\hline
\end{tabular}

\section{Appendix B: Robustness Tests}

\section{Firm Size}

Old firms could be relatively unattractive merger partners because they are larger, and the costs of absorbing larger targets are higher (Palepu, 1986). Tables II and III do control for firm size. Size, however, could have a 
different impact on the takeover likelihood of young and old firms, which could explain the negative relation between takeover hazard and age.

To find out, we add an interaction term of s Size and b Old to our standard competing risk model in Table III (M-Logit 3). Measuring company age with $b$ Old facilitates the interpretation. The conclusions are the same when we measure age with $\ln ($ Age). The results are in the first section of Table AIII. For convenience, the section reports only the coefficients of b Old, s Size, and the interaction term of s Size with b Old. According to the results, allowing for different coefficients of size depending on firm age does not erase the negative coefficient of age.

\section{Imbalance between Growth Opportunities and Available Resources}

Palepu (1986) and Powell and Yawson (2007) argue that takeover threats materialize because of an imbalance between growth opportunities and available resources. If these imbalances declined over time, company age could be a proxy for reduced imbalances. The second section of Table AIII tests that possibility. We assume there is an imbalance between growth and available resources (b Growth-resource imbalance) when a firm exhibits one of the following characteristics: (i) below-average growth opportunities and above-average cash holdings or (ii) above-average growth opportunities and below-average cash holdings. The results show, however, that $\mathrm{b}$ Old maintains its negative and significant coefficient.

\section{Decreased Dissipation of Resources over Time}

It could also be that the market for corporate control prevents the dissipation of resources (Schumpeter, 1975; Jensen, 2000). We measure the waste of resources with an interaction term of high discretionary investments and low growth opportunities. Discretionary investments are, alternatively, R\&D and capital expenditures (see, e.g., Minton and Schrand, 1999). Loderer, Stulz, and Waelchli (2014) show that these activities decline as firms get older. Hence, the potential dissipation problem, which takeover could correct, declines over time. That could explain the negative relation between company age and takeover hazard. To test this interpretation, we add the interaction term to our competing risk model. The results are in the third section of the Table AIII. The coefficient of company age remains negative and significant, regardless of how we measure discretionary investments. 


\section{Company Age versus Age of Managers and Directors}

Older firms have older managers (Loderer, Stulz, and Waelchli, 2014), and older managers could try to protect their jobs. What looks like a firm age effect could actually be a management age effect. To find out, we collected data on CEO and director age from ExecuComp and Risk Metrics, respectively. ${ }^{6}$ We then reestimated the competing risk model with the alternative addition of two binary variables that measure above average ages of CEO and directors, respectively. According to the fourth section of Table AIII, firms with old boards face indeed a significantly lower takeover risk. Also firms with old CEOs do, although the coefficient is significant only in a one-sided test. However, and more important, the coefficient of firm age remains negative and significant in both regressions. If anything, it is numerically larger.

Jenter and Lewellen (2014) find that takeover likelihood increases once the $\mathrm{CEO}$ has reached retirement age. We reestimated the regression specification in the third section and controlled for the presence of CEOs with age 65 years and higher. The coefficient of company age, however, remained negative and significant. As in Jenter and Lewellen (2014), old CEOs tend to increase the likelihood of takeover, but the effect was statistically insignificant (not shown).

\section{Company Age and Management Talent}

The firm age effect could also reflect management talent. If older organizations were more likely to be managed by talented individuals, they would be managed efficiently, which could explain why takeover risk drops over time. We used CEO tenure and CEO total compensation as proxies for talent and included these variables as additional controls in our hazard model. According to the results, however, the coefficient of firm age remained negative and significant (not shown). The coefficients of CEO tenure and CEO total compensation were statistically zero.

\section{Industry Age}

Merger activity could be concentrated in young, unconsolidated industries. Small players in those industries might merge to achieve the necessary economies of scale (so-called roll-up mergers; see, e.g., Bower, 2001). If firm age was correlated with industry age, a negative firm age dependence

6 Data on CEO age start in 1992, and data on director age are available from 1996. 
of takeover hazard would follow quite naturally. To address the issue of industry age, the fifth section of Table AIII expands our hazard model with the addition of a binary variable that identifies firms that operate in relatively mature industries (b Old industry) and an interaction term of that variable with $b$ Old. We test whether under this specification the negative age-dependence of takeover hazard disappears. Yet it does not. The old firm dummy b Old maintains its negative and significant coefficient.

\section{References}

Agarwal, R. and Gort, M. (1996) The evolution of markets and entry, exit and survival of firms, Review of Economics and Statistics 78, 489-498.

Agarwal, R. and Gort, M. (1999) The determinants of firm survival. Working paper, University of Central Florida, SUNY at Buffalo.

Agarwal, R. and Gort, M. (2002) Firm product life cycles and firm survival, American Economic Review 92, 184-190.

Anderson, M. C., Banker, R. D., and Janakiraman, S. N. (2003) Are selling, general, and administrative costs "sticky"? Journal of Accounting Research 41, 47-63.

Andrade, G., Mitchell, M., and Stafford, E. (2001) New evidence and perspectives on mergers, Journal of Economic Perspectives 15, 103-120.

Arikan, A. M. and Stulz, R. M. (2013) Corporate acquisitions, diversification, and the firm's lifecycle. Working paper, Ohio State University.

Baker, G. P. and Kennedy, R. E. (2002) Survivorship and the economic grim reaper, Journal of Law, Economics, and Organization 18, 324-361.

Berchtold, D., Loderer, C., and Waelchli, U. (2014) Core abilities, divestitures, and the corporate lifecycle. Working paper, University of Bern.

Bertrand, M. and Mullainathan, S. (2003) Enjoying the quiet life? Corporate governance and managerial preferences, Journal of Political Economy 111, 1043-1075.

Bharath, S. T. and Shumway, T. (2008) Forecasting default with the Merton distance to default model, Review of Financial Studies 21, 1339-1369.

Bhattacharya, U., Borisov, A., and Yu, X. (2014) Firm mortality and natal financial care, Journal of Financial and Quantitative Analysis, forthcoming.

Bower, J. L. (2001) Not all M\&As are alike - and that matters, Harvard Business Review 79, 92-101.

Bruner, R. F. (1988) The use of excess cash and debt capacity as a motive for merger, Journal of Financial and Quantitative Analysis 23, 199-217.

Bushman, R., Chen, Q., Engel, E., and Smith, A. (2004) Financial accounting information, organizational complexity and governance systems, Journal of Accounting and Economics 37, $167-201$.

Cameron, A. C. and Trivedi, P. K. (2005) Microeconometrics-Methods and Applications, Cambridge University Press, Cambridge.

Campbell, J. Y., Hilscher, J., and Szilagyi, J. (2008) In search of distress risk, Journal of Finance 63, 2899-2939.

Cao, J. X. and Lerner, J. (2009) The performance of reverse leveraged buyouts, Journal of Financial Economics 91, 139-157. 
Coates, J. C. (2000) Takeover defenses in the shadow of the pill: a critique of the scientific evidence, Texas Law Review 79, 271-382.

Comment, R. and Schwert, G. W. (1995) Poison or placebo? Evidence on the deterrence and wealth effects of modern antitakeover measures, Journal of Financial Economics 39, $3-43$.

Cooley, T. F. and Quadrini, V. (2001) Financial markets and firm dynamics, American Economic Review 91, 1286-1310.

Core, J. E., Guay, W. R., and Rusticus, T. O. (2006) Does weak governance cause weak stock returns? An examination of firm operating performance and investors' expectations, Journal of Finance 61, 655-687.

Daines, R. and Klausner, M. (2001) Do IPO charters maximize firm value? Antitakeover protection in IPOs, Journal of Law, Economics, and Organization 17, 83-120.

DeAngelo, H. and Rice, E. M. (1983) Antitakeover charter amendments and stockholder wealth, Journal of Financial Economics 11, 329-359.

Denis, D. J., Denis, D. K., and Yost, K. (2002) Global diversification, industrial diversification, and firm value, Journal of Finance 57, 1951-1979.

EY (2014) The Right Combination: Managing Integration for Deal Success, London, UK.

Fama, E. F. and French, K. R. (2004) New lists: fundamentals and survival rates, Journal of Financial Economics 73, 229-269.

Field, L. C. and Karpoff, J. M. (2002) Takeover defenses of IPO firms, Journal of Finance 57, 1857-1889.

Fink, J., Fink, K. E., Grullon, G., and Weston, J. P. (2010) What drove the increase in idiosyncratic volatility during the internet boom? Journal of Financial and Quantitative Analysis 45, 1253-1278.

Giroud, X. and Mueller, H. M. (2010) Does corporate governance matter in competitive industries?, Journal of Financial Economics 95, 312-331.

Gompers, P., Lerner, J., and Scharfstein, D. (2005) Entrepreneurial spawning: public corporations and the genesis of new ventures, 1986 to 1999, Journal of Finance 60, 577-614.

Gopalan, R. and Xie, K. (2011) Conglomerates and industry distress, Review of Financial Studies 24, 3642-3687.

Grossman, S. J. and Hart, O. D. (1988) One share-one vote and the market for corporate control, Journal of Financial Economics 20, 175-202.

Hadlock, C. J. and Pierce, J. R. (2010) New evidence on measuring financial constraints: moving beyond the KZ index, Review of Financial Studies 23, 1909-1940.

Hartzell, J. C., Ofek, E., and Yermack, D. (2004) What's in it form me? CEOs whose firms are acquired, Review of Financial Studies 17, 37-61.

Heckman, J. J. and Singer, B. (1984) A method for minimizing the impact of distributional assumptions in econometric models for duration data, Econometrica 52, 271-320.

Henderson, R. (1993) Underinvestment and incompetence as responses to radical innovation: evidence from the photolithographic alignment equipment industry, Rand Journal of Economics 24, 248-270.

Hicks, J. R. (1935) Annual survey of economic theory: the theory of monopoly, Econometrica 3, 1-20.

Hoberg, G. and Phillips, G. (2010) Product market synergies and competition in mergers and acquisitions: a text-based analysis, Review of Financial Studies 23, 3773-3811.

Hoberg, G., Phillips, G., and Prabhala, N. R. (2014) Product market threats, payouts, and financial flexibility, Journal of Finance 69, 293-324. 
Holmstrom, B. (1989) Agency costs and innovation, Journal of Economic Behavior and Organization 12, 305-327.

Jenkins, S. P. (2005) Survival analysis. Lecture notes, University of Essex, ISER.

Jensen, M. C. (1986) Agency costs of free cash flow, corporate finance, and takeovers, American Economic Review 76, 323-329.

Jensen, M. C. (1988) Takeovers: their causes and consequences, Journal of Economic Perspectives 2, 21-48.

Jensen, M. C. (1993) The modern industrial revolution, exit, and the failure of internal control systems, Journal of Finance 48, 831-880.

Jensen, M. C. (2000) A Theory of the Firm: Governance, Residual Claims, and Organizational Forms, Harvard University Press, Cambridge, MA.

Jenter, D. and Lewellen, K. (2014) CEO preferences and acquisitions, Journal of Finance. forthcoming.

Jovanovic, B. (1982) Selection and the evolution of industry, Econometrica 50, 649-670.

Jovanovic, B. and Rousseau, P. L. (2001) Why wait? A century of life before IPO, American Economic Review 91, 336-341.

Jovanovic, B. and Rousseau, P. L. (2002) The Q-theory of mergers, American Economic Review 92, 198-204.

Kole, S. R. and Lehn, K. (1997) Deregulation, the evolution of corporate governance structures, and survival, American Economic Review 87, 421-425.

Kole, S. R. and Lehn, K. (1999) Deregulation and the adaption of governance structure: the case of the U.S. airline industry, Journal of Financial Economics 52, 79-117.

Lehn, K. and Poulsen, A. B. (1989) Free cash flow and stockholder gains in going private transactions, Journal of Finance 44, 771-787.

Leonard-Barton, D. (1992) Core capabilities and core rigidities: a paradox in managing new product development, Strategic Management Journal 13, 111-125.

Loderer, C., Stulz, R. M., and Waelchli, U. (2014) Why do older firms have fewer growth opportunities? Working paper, Ohio State University, University of Bern.

Manne, H. G. (1965) Mergers and the market for corporate control, Journal of Political Economy 73, 110-120.

Merton, R. C. (1974) On the pricing of corporate debt: the risk structure of interest rates, Journal of Finance 29, 449-470.

Meyer, B. D. (1990) Unemployment insurance and unemployment spells, Econometrica 58, 757-782.

Minton, B. A. and Schrand, C. (1999) The impact of cash flow volatility on discretionary investment and the costs of debt and equity financing, Journal of Financial Economics 54, 423-460.

Mitchell, M. L. and Mulherin, J. H. (1996) The impact of industry shocks on takeover and restructuring activity, Journal of Financial Economics 41, 193-229.

Morck, R., Shleifer, A., and Vishny, R. W. (1989) Alternative mechanisms for corporate control, American Economic Review 79, 842-852.

Murphy, K. (1997) Executive compensation and the Modern Industrial Revolution, International Journal of Industrial Organization 15, 417-425.

Norton, E. C., Wang, H., and Ai, C. (2004) Computing interaction effects and standard errors in logit and probit models, Stata Journal 4, 154-167.

Opler, T. C. and Titman, S. (1994) Financial distress and corporate performance, Journal of Finance 49, 1015-1040. 
Palepu, K. G. (1986) Predicting takeover targets: a methodological and empirical analysis, Journal of Accounting and Economics 8, 3-35.

Pastena, V. and Ruland, W. (1986) The merger/bankruptcy alternative, Accounting Review 61, 288-301.

Pastor, L. and Veronesi, P. (2003) Stock valuation and learning about profitability, Journal of Finance 58, 1749-1789.

Powell, R. G. and Yawson, A. (2007) Are corporate restructuring events driven by common factors? The implications for takeover predictions, Journal of Business Finance \& Accounting 94, 101-124.

Prentice, R. L. and Gloeckler, L. A. (1978) Regression analysis of grouped survival data with application to breast cancer data, Biometrics 34, 57-67.

Rauh, J. D. (2006) Own company stock in defined contribution pension plans: a takeover defense? Journal of Financial Economics 81, 379-410.

Rhodes-Kropf, M. and Robinson, D. T. (2008) The market for mergers and the boundaries of the firm, Journal of Finance 63, 1169-1211.

Scharfstein, D. (1988) The disciplinary role of takeovers, Review of Economic Studies 55, 185-199.

Schumpeter, J. A. (1975) Capitalism, Socialism and Democracy, Harper, New York.

Schwert, G. W. (2000) Hostility in takeovers: in the eyes of the beholder? Journal of Finance 55, 2599-2640.

Servaes, H. (1991) Tobin's Q and the gains from takeovers, Journal of Finance 46, 409-119.

Shrievens, R. E. and Stevens, D. L. (1979) Bankruptcy avoidance as a motive for merger, Journal of Financial and Quantitative Analysis 14, 501-515.

Shumway, T. (2001) Forecasting bankruptcy more accurately: a simple hazard model, Journal of Business 74, 101-124.

Stiglitz, J. E. (1972) Some aspects of the pure theory of corporate finance: bankruptcies and takeover, Bell Journal of Economics and Management Science 3, 458-482.

Thompson, P. (2005) Selection and firm survival: evidence from the shipbuilding industry, 1825-1914, Journal of Economics and Statistics 87, 26-36.

Zorn, C. J. W. (2000) Modeling duration dependence, Political Analysis 8, 367-380. 